Volume 8 | Issue 3

4-30-2021

\title{
Children Are Human
}

Kim Pearson

Gonzaga University, pearsonk@gonzaga.edu

Follow this and additional works at: https://scholarship.law.tamu.edu/lawreview

Part of the Civil Law Commons, Domestic and Intimate Partner Violence Commons, Family Law Commons, Family, Life Course, and Society Commons, and the Juvenile Law Commons

\section{Recommended Citation}

Kim Pearson, Children Are Human, 8 Tex. A\&M L. Rev. 495 (2021).

Available at: https://doi.org/10.37419/LR.V8.I3.2

This Article is brought to you for free and open access by Texas A\&M Law Scholarship. It has been accepted for inclusion in Texas A\&M Law Review by an authorized editor of Texas A\&M Law Scholarship. For more information, please contact aretteen@law.tamu.edu. 


\title{
CHILDREN ARE HUMAN
}

\author{
by: Kim Hai Pearson*
}

\begin{abstract}
There are great benefits to be had should the United States, one of the global leaders in economic strength and political power, ratify the United Nations Convention on the Rights of the Child ("CRC"). The mystery of the United States's ultimate reluctance to ratify the CRC, despite the nation's central role in the drafting process, has been interrogated for years. Scholars and policymakers have developed compelling narratives regarding obstacles to the United States's ratification and implementation of the CRC. However wellreasoned the arguments for ratification are, there has been little progress in persuading the United States to ratify the CRC.

While the work toward ratification should continue on every level, informal implementation before ratification would be advantageous and in line with historical methods of reform in the United States. One area that has been overlooked to the advantage of minority and vulnerable populations is domestic relations courts in the United States. In the United States, children's rights advocacy work should be conducted like cause advocacy for historically disfavored groups to achieve legal recognition and protection of their rights. For example, parenting equality efforts were primarily focused on creating change in individual courts over time, allowing advocates to teach judicial officers and other legal decision-makers about positive outcomes for children of lesbian and gay parents while dispelling myths, misperceptions, and negative stereotypes about sexual minorities. Similarly, other disfavored parents, like working mothers, religious, and racial minorities, have used individual court cases to advocate and educate until new, progressive norms are adopted as national standards. Advocates for children's rights should adopt institutional change theory and tailor cause advocacy efforts to implement the CRC principles in local domestic relations courts. Focusing on change from within institutions may shift legal norms more quickly, so children are recognized as fully human and thus rights holders in the United States, rather than relying on external legislative changes.
\end{abstract}

DOI: https://doi.org/10.37419/LR.V8.I3.2

* Professor of Law and Associate Dean of Academic Affairs and Program Innovation, Gonzaga University School of Law. I wish to thank my dissertation supervisor, Nevena Vučković-Šahović, for her unwavering support and excellent guidance in this project. My thanks to my writing group in the Oxford University IHRL 2017-2019 cohort. To Robin Lehnhardt, Jessica Kiser, Mason Marks, and Doug NeJaime, my gratitude for reviewing my manuscript and providing excellent comments. I have also benefitted from comments and suggestions made by Hiroshi Motomura, Nancy Cantalupo, Stewart Chang, and Andrea Y. Wang during the 2018 CAPALF/WLPOC conference and the invaluable support of colleagues, like Nancy Dowd, Jessica Dixon Weaver, Cynthia Godsoe, Rachel Rebouche, Seema Mohaptra Reddy, and the attendees of the 2018 Family Law Scholars and Teachers Conference held at the University of Minnesota. My gratitude to law librarians Pat Charles and Ashley Sundin for their expert support and my research assistants, Jerusha Dressel, Tsveta Ivanona Kelly, and Jonathan Bisceglia for their help. To the excellent staff at Texas A\&M University School of Law I extend my gratitude and praise for a wonderful editing experience and their enthusiasm for legal discourse. 
TABle of Contents

I. Introduction................................ 496

II. The CRC and the United States as the Lone

Holdout ....................................... 502

III. Progress in the United States? ............... 516

IV. Radical Reform in Domestic Relations Courts .. 524

V. Conclusion ................................ 533

\section{INTRODUCTION}

"The children are always ours, every single one of them, all over the globe; and I am beginning to suspect that whoever is incapable of recognizing this may be incapable of morality."

_James Baldwin ${ }^{1}$

Resistance to international human rights law continues to pervade the United States legal system. The United States is the only member state of the United Nations to not ratify the CRC, ${ }^{2}$ one of the most widely supported core human rights conventions. The CRC "reflects universal aspirations and standards for the recognition, care, and protection of our most vulnerable population-children." ${ }^{3}$ In the recent past, the United States ratified Optional Protocols ("OP") to the CRC, which address children in armed conflict ("OPAC") 4 and combat the exploitation, trafficking, and use of children in pornography ("OPSC"). ${ }^{5}$ Optimists may consider the United States's ratification of the CRC's OPs as a sign of progress. However, the United States took pains to ensure that the OPs could be ratified without ratifying the main Convention itself.

There are compelling and persuasive theories about the United States's resistance to ratifying the CRC and endorsing it as the "authoritative expression of children's rights." 6 The primary reasons

1. James Baldwin, Notes on the House of Bondage, NAtion (Nov. 1, 1980), https:/ /www.thenation.com/article/notes-house-bondage [https://perma.cc/T442-96CC].

2. Yvonne Vissing, Child Rights in the United States: 25 Years Later and Counting, in The United Nations Convention on the Rights of the Child: Taking Stock After 25 years and Looking Ahead 73 (Ton Liefaard \& Julia Sloth-Nielsen eds., 2017).

3. Cris R. Revaz, An Introduction to the U.N. Convention on the Rights of the Child, in The U.N. Convention on the Rights of the Child: An Analysis of Treaty Provisions and Implications of U.S. Ratification 9 (Jonathan Todres, Mark E. Wojcik \& Cris R. Revaz eds., 2006).

4. G.A. Res. 54/263, annex I, Optional Protocol to the Convention on the Rights of the Child on the Involvement of Children in Armed Conflict (May 25, 2000) [hereinafter Children in Armed Conflict].

5. G.A. Res. 54/263, annex II, Optional Protocol to the Convention on the Rights of the Child on the Sale of Children, Child Prostitution and Child Pornography (May $25,2000)$.

6. Jonathan Todres, Analyzing the Opposition to U.S. Ratification of the U.N. Convention on the Rights of the Child, in THE U.N. Convention on THE Rights of 
presented are (1) sovereignty concerns based on attitudes that the United States is a moral force in international laws, but should be immune from international jurisdiction; (2) the current legal regime subsumes children's rights into parents' rights or, in the alternative, to local state government; and (3) popular beliefs that children in the United States have adequate legal protection in the existing system. The central concerns that prevent the United States from ratifying the CRC continue to exist and appear to be, in the current political landscape, filled with nationalistic, isolationist rhetoric, which is more persistent than ever. ${ }^{7}$

The current United States legal system cannot intervene effectively on behalf of children. ${ }^{8}$ The system does not recognize that children are fully human and rights holders. Instead, it conflates the concept of "not fully adult" with "not fully human" and "incapable of being a rights holder." In recent years, the juvenile justice system has made progress in recognizing children's diminished decision-making capacity. Notably, children in the United States can be tried as adults based on the nature and severity of their crimes; during the 1990s, "approximately 210,000 to 260,000 children under the age of eighteen were processed in the adult court." 10 Only in recent years have advocates fought for recognition that children have diminished capacity to understand the consequences of their actions and therefore should not be held to adult standards of accountability. ${ }^{11}$

Childhood, in the United States's popular imagination, is a time of innocence to be protected by adults. ${ }^{12}$ Traditionally, the locus of children's interests in the United States's legal imagination has been settings like custody, removal, adoption, welfare, and dependencyareas where children's interests link up with parents' rights and are only seen as interests via adults' articulation of children's best inter-

the Child: An Analysis of Treaty Provisions and Implications of U.S. RatiFICATION 19 (Jonathan Todres, Mark E. Wojcik \& Cris R. Revaz eds., 2006).

7. See Vissing, supra note 2, at 73-74.

8. See id. at 82 .

9. Barbara Bennett Woodhouse, The Changing Status of the Child, in THE U.N. Convention on the Rights of the Child: An Analysis of Treaty Provisions And Implications of U.S. Ratification 51 (Jonathan Todres, Mark E. Wojcik \& Cris R. Revaz eds., 2006).

10. Rosemary C. Sarri \& Jeffrey J. Shook, Human Rights and Juvenile Justice in the United States, in Children's Human Rights 197, 209 (Mark Ensalaco \& Linda C. Majka eds., 2005).

11. See generally Thomas Grisso et al., Juveniles' Competence to Stand Trial: A Comparison of Adolescents' and Adults' Capacities as Trial Defendants, 27 L. \& Hum. Behav. 333 (2003); Roper v. Simmons, 543 U.S. 551, 570 (2005).

12. See generally Kathryn Bond Stockton, The Queer Child, or Growing Sideways in the Twentieth Century (2009); Viviana A. Zelizer, Pricing the Priceless Child: The Changing Social Value of Children (1981); David F. Lancy, The Anthropology of Childhood: Cherubs, Chattel, Changelings (2d ed. 2015). 
ests. ${ }^{13}$ There has been little need conceptually to separate children's rights from parent's rights. The current legal regime that addresses children, family law, welfare and dependency, and juvenile law is believed to be a responsive and satisfactory model of rights, based solely on protecting children as a vulnerable population, not as agentic subjects. However, there are children's issues that are becoming more pressing domestically that do not fit within the traditional model of protecting children's rights through the conduit of parental rights and interests.

As more issues that United States citizens perceive to be the preserve of international law ${ }^{14}$ make their way into domestic law settings, the demands for solutions will quickly outstrip capacity in the United States legal system. United States legal frameworks, such as domestic relations courts as they are currently constituted, are not likely to be prepared to humanely address issues. These children face unique challenges, such as international trafficking, transborder travel, widespread sexual assault of migrant children by United States government agents, ${ }^{15}$ and trauma from childhood violence, circumstances that result from the spreading effects of global armed conflicts, war, and natural disasters. Additionally, Special Rapporteur Professor Phillip Alston's 2017 report revealed that problems thought to plague

13. See generally Meyer v. Nebraska, 262 U.S. 390 (1923); Pierce v. Soc'y of the Sisters of the Holy Names of Jesus \& Mary, 268 U.S. 510 (1925).

14. See, e.g., Sam McFarland, International Differences in Support for Human Rights, 12 Societies Without Borders 1, 13-14 (2017) (stating United States citizens generally support civil rights over economic rights, but attitudes about global cooperation to support civil rights remain divided, meaning that there is a political divide regarding how the United States should treat other countries); see generally Public Uncertain, Divided Over America's Place in the World, Pew Rsch. CTR. (2016), http://www.pewresearch.org/wp-content/uploads/sites/4/2016/05/05-05-2016Foreign-policy-APW-release.pdf [https://perma.cc/DU7J-KMPE]. Unsurprisingly, there are beliefs that individual states should be responsible for problems such as natural disasters, economic challenges, development, and sustainability in light of American attitudes toward individual wealth or poverty, as opposed to beliefs that it is the government's responsibility to set policies that promote income equality. Another effect of isolationist and individualist attitudes in the United States is its withdrawal from the global stage as a leader in human rights law. See Michael Posner, Why U.S. Withdrawal from the Human Rights Council Is a Dangerous Leadership Mistake, Forbes (June 19, 2018, 5:50 PM), https://www.forbes.com/sites/ michaelposner/2018/06/19/u-s-withdrawal-from-the-un-human-rights-council/

\#67616ad3de2b [https://perma.cc/39Y9-XJ7U] (opining about the United States's "headlong retreat from the [global] leadership position it has occupied since World War II"); Stewart M. Patrick, Human Rights Safeguards Take a Backseat in New Global Economics Institutions, Council Foreign Rels. (Sept. 6, 2018), https:// www.cfr.org/blog/human-rights-safeguards-take-backseat-new-global-economics-institutions [https://perma.cc/D64A-Y7MT] (observing that the U.S. "appears to be relinquishing its role as a proponent of international human rights").

15. Mathew Haag, Thousands of Immigrant Children Said They Were Sexually Abused in U.S. Detention Centers, Report Says, N.Y. Times (Feb. 27, 2019), https:// www.nytimes.com/2019/02/27/us/immigrant-children-sexual-abuse.html [https:// perma.cc/2XJZ-5QNP]. 
only developing states occur in the United States. ${ }^{16}$ He reported data about the extreme poverty of 13.3 million children in the United States. ${ }^{17}$ The rate of school shootings is on the rise. ${ }^{18}$ And while domestic child removal rates have decreased in recent years, the problem persists. ${ }^{19}$ Finally, vulnerable children who are forcibly separated from parents, ${ }^{20}$ or who arrive without parents and then are detained by the United States government while migrating, ${ }^{21}$ present a moral dilemma for a society that claims to protect children. Rather than relying on political or social change alone to prompt ratification and implementation of the CRC, children's rights advocates should follow juvenile justice's cooperation model. ${ }^{22}$ Combining international human rights principles with juvenile justice legal advocacy created a model for changing United States legal protection for juveniles in the

16. Philip Alston, Statement on Visit to the USA, by Professor Philip Alston, United Nations Special Rapporteur on Extreme Poverty and Human Rights, UnITED Nations Hum. Rts. Off. High Comm'r (Dec. 15, 2017), https://www.ohchr.org/EN/ NewsEvents/Pages/DisplayNews.aspx?NewsID=22533 [https://perma.cc/NBM8U6YZ].

17. Id.

18. See Study Confirms Steady Rise in School Shootings, WebMD (Jan. 24, 2019), https://www.webmd.com/mental-health/news/20190124/study-confirms-steady-rise-inschool-shootings\#1 [https://perma.cc/K46K-UCMZ].

19. Child Welfare Outcomes 2010-2014: Report to Congress, U.S. DeP'T Health \& Hum. Servs.: Child.'s Bureau i-ii (July 14, 2017), https://www.acf.hhs.gov/cb/ resource/cwo-10-14 [https://perma.cc/SX6Z-XVXV] (reporting decrease in number of children in foster care in the years 2005-2014, from 515,000 to 415,000; however, the decrease was significant for years 2010-2013 at 400,000, increasing again in 2014 to 415,000); see also Child Welfare Outcomes 2015: Report to Congress, U.S. DeP'T Health \& Hum. Servs.: Child.'s Bureau ii (June 13, 2018), https:// www.acf.hhs.gov/cb/resource/cwo-2015 [https://perma.cc/J5QG-CDRW] (reporting 428,000 children in foster care in 2015); Number of Children in Foster Care Continues to Increase, U.S. Dep't Health \& Hum. Servs.: Admin. for Child. \& Fams. (Nov. 30, 2017), https://www.acf.hhs.gov/media/press/2017/number-of-children-in-fostercare-continues-to-increase [https://perma.cc/4U2D-UM2Z] (reporting that at the end of the fiscal year 2016, the number of children in foster care was 437,500).

20. Camila Domonoske \& Richard Gonzales, What We Know: Family Separation and 'Zero Tolerance' at the Border, NAT'L PuB. Radio (June 19, 2018, 2:17 PM), https://www.npr.org/2018/06/19/621065383/what-we-know-family-separation-and-zerotolerance-at-the-border [https://perma.cc/7SVY-3ZQ2].

21. See Caitlin Dickerson, Detention of Migrant Children Has Skyrocketed to Highest Levels Ever, N.Y. TIMEs (Sept. 12, 2018), https://nyti.ms/2Nat9tC [https:// perma.cc/Y4UL-DMTY]; see also ACLU Obtains Documents Showing Widespread Abuse of Child Immigrants in U.S. Custody, Am. C.L. Union (May 22, 2018), https:// www.aclu.org/news/aclu-obtains-documents-showing-widespread-abuse-child-immigrants-us-custody [https://perma.cc/HG6A-T5RH] (detailing abuses suffered by unaccompanied minor immigrant children); Dan Barry et al., Cleaning Toilets, Following Rules: A Migrant Child's Days in Detention, N.Y. TIMEs (July 14, 2018), https:// nyti.ms/2NQcb0D [https://perma.cc/AHF9-V59B].

22. See Bernardine Dohrn, The Surprising Role of the CRC in a Non-State-Party, in Litigating the Rights of the Child: The UN Convention on the Rights of The Child in Domestic and International Jurisprudence 84-85 (Ton Liefaard \& Jaap E. Doek eds., 2015) (explaining that juvenile justice reform involved a complex strategy that integrated international standards). 
criminal system. ${ }^{23}$ In the same vein, CRC advocates could work with institutional, legal actors at the domestic court level to create the conditions for implementing the CRC principles. Viewing the entirety of domestic relations courts as an institution writ large, rather than as individual, regional, local entities, opens up new approaches to introducing the CRC core principles into the United States's legal landscape. Of particular interest and relevance is institutional change theory.

Institutional change theory describes how institutions change; changing over time in positive directions is one option. Where there is ambiguity in interpretation of the rules and insiders act to improve, not destroy, the institution by maximizing the change through interpretation refers to "conversion" in institutional change theory. ${ }^{24}$ In the United States, the little-seen and often-used battleground for shaping social norms around childhood, parenting, marriage, and sexuality takes place in domestic relations courts. ${ }^{25}$ There is greater discretion in the judiciary to interpret the few standards available-most of which are lists of factors ${ }^{26}$ that help guide judges in making decisions for the individuals at bar, not for national advocacy groups interested in large-scale legal gestures to spur reform. Instead, each individual case builds over time into a sort of national standard as more states make decisions about various socio-legal issues in the context of domestic relations. Importantly, these courts are spaces for radical reform in which children's rights advocates should use "conversion" to introduce CRC principles everyday legal parlance about children and families. ${ }^{27}$

This piece contains three parts. Part Two provides a brief overview of the CRC, explaining why it is a critical, core human rights convention. This Part presents justifications for the United States's refusal to ratify the $\mathrm{CRC}$ as a socio-political matter. However, no matter the justifications for refusing to ratify or the critiques levelled against the CRC, the United States should not continue refusing to incorporate international human rights principles. There is no requirement to en-

23. $I d$.

24. Id. at $17-18$.

25. Timothy E. Lin, Social Norms and Judicial Decisionmaking: Examining the Role of Narratives in Same-Sex Adoption Cases, 99 Colum. L. Rev. 739, 766-68 (1999) (discussing how judicial decisions reflect and influence social norms).

26. See, e.g., Barbara A. Atwood, Representing Children Who Can't or Won't Direct Counsel: Best Interests Lawyering or No Lawyer at All?, 53 ARIz. L. Rev. 381, 417 (2011) (discussing the importance of the court's discretion in child abuse cases); In re Marriage of Patterson, 920 P.2d 450, 454 (Kan. Ct. App. 1996) (discussing the guidelines that the Kansas Supreme Court adopted for child support cases).

27. James Mahoney \& Kathleen Thelen, A Theory of Gradual Institutional Change, in Explaining Institutional Change: Ambiguity, Agency, and Power 18 (James Mahoney \& Kathleen Thelen eds., 2010). 
force all of the CRC mandates, ${ }^{28}$ and ratification would be an expressive act that signals inclusion in the international community as a peer, not a colonizing force that makes laws but does not submit itself to them.

The second Part provides a snapshot of conditions for children internationally and in the United States. The exceptionalism that obscures mainstream perceptions about children in developing economic states as compared to children in the United States may be contributing to pushback against the CRC. Popular belief in the United States is that children in the United States do not need the protection of the CRC. $^{29}$ As data begins to show otherwise-that the children are not all right - the United States may be prepared to begin shoring up children's rights with international human rights principles. ${ }^{30}$ This Part next presents the progress made in the realm of United States juvenile justice and explores the role international human rights played in recent decisions, demonstrating that children are a compelling matter of concern and strategic cause advocacy is a formula that works to move the United States toward embracing human rights principles. The strides made in United States juvenile death penalty and detention cases can be transferred to other areas of law that touch on children's rights by employing a similar framework of institutional "conversion." 31 If children's rights advocates in the United States conceptualize the recent progress made in juvenile justice issues as an example of institutional change theory at work and transfer it to other legal settings where it can also be effective, the aspiration of implementing the CRC's principles into the United States legal system can be realized.

The third Part explores the possibility that institutional change theory, particularly "conversion" of an institution by insiders to better and more progressive actions, is the most promising route toward creating the conditions necessary for the United States to ratify and implement the human rights principles embodied in the CRC. An excellent example of the space in which radical reform by "conversion" would work is the vast network of United States domestic relations courts.

The state courts, as opposed to federal district courts, are both the laboratory of the nation-state that serve in producing, over time, the legal contours of socio-political issues and the trenches in which daily, seemingly small skirmishes turn into the roots of the national legal

28. Patrick Geary, CRC in Court: The Case Law of the Convention on the Rights of the Child, Child. RTs. Int'L Network 1, 5 (2012), https://archive.crin.org/docs/ CRC_in_Court_Report.pdf [https://perma.cc/BMS3-8ESL].

29. Joe Lauria, Why Won't the US Ratify the UN's Children's Rights Convention?, HufFington Post, https://www.huffpost.com/entry/why-wont-the-us-ratify-th_b_61 95594 (Jan. 25, 2015) [https://perma.cc/DCG9-HGTE].

30. Charles M. Blow, Opinion, The Kids Are (Not) All Right, N.Y. Times (April 17, 2013), https://nyti.ms/100RYDb [https://perma.cc/K4JB-DG8X].

31. See Dohrn, supra note 22, at 84-85. 
standards for families and children. ${ }^{32}$ Other disfavored and marginalized groups have long fought for their civil rights, religious liberty, gender equality, and other progressive ideals in local domestic relations courts. In the same way that marginalized groups have rallied and advocated using strategic litigation advocacy, so too should children's rights advocates harness the possibility of institutional "conversion" to introduce and normalize the CRC principles into the legal discourse regarding children and families. Accordingly, the conditions would be ripe for embracing the CRC. The conditions would be created (much like they were for ratifying the Optional Protocols related to child soldiers, exploitation, trafficking, and pornography) for CRC principles to be seen as natural extensions of existing United States law and policy.

\section{The CRC and the United States as the Lone Holdout}

Unsurprisingly, the United States has long had an isolationist and individualist approach to international relationships, particularly in the realm of international human rights. The possibility that international standards and punishments would be imposed on the United States is framed in the United States as an abhorrent abdication of self-governance rights. ${ }^{33}$ Nonetheless, the willingness to impose United States's norms, laws, and punishments is perceived as natural by the same polity due to the popular perception that the United States has the moral high ground in human rights, civilization, economic status, and power on the international scene stemming from its cherished self-conception as a "city upon a hill," ${ }^{34}$ shining as a moral guide for others. ${ }^{35}$ The seeming lack of awareness regarding the conceptual disconnect between the United States's role in drafting treaties, including imposing norms and standards from the United States into treaty mandates, and its refusal to be subject to such treaties is disappointing to the global human rights community and not surpris-

32. See Lin, supra note 25 , at 766-68 (discussing how judicial decisions reflect and influence social norms).

33. See Lauria, supra note 29.

34. See John Winthrop, A Model of Christian Charity 47 (1630); John F. Kennedy, U.S. President-Elect, City Upon a Hill Speech (Jan. 9, 1961) (transcript available in the John F. Kennedy Library \& Museum); Ronald Reagan, U.S. President, Farewell Address (Jan. 11, 1989) (transcript available in the Ronald Reagan Presidential Library and Museum); George W. Bush, U.S. President, Address to Joint Session of Congress Following 9/11 Attacks (Sept. 20, 2001) (transcript available in the Washington Post Archives).

35. See, e.g., Alexis de Tocoueville, Democracy in America, Volume II, ch. IX (Henry Reeve trans., 2013) (the call to be as a light shining on the hill is a biblical reference used to describe and justify the colonization of pre-existing societies in the Americas as religious groups settled in the northeastern coast of North America. Alexis de Tocqueville is the first to describe America as "exceptional" and, citing to John Winthrop, tying the city on the hill imagery with American exceptionalism together). 
ing given the exceptionalist attitude toward international human rights law despite the United States's critical role in designing international rights systems post-World War II. ${ }^{36}$

The mistaken belief that children are all doing well ${ }^{37}$ in the United States without the CRC-and that therefore there is no obligation to support the CRC-is only part of the problem when it comes to obstructing ratification and implementation of the treaty. The mistake is two-fold. The first is that there are children suffering from poor health and negative social outcomes in the United States. ${ }^{38}$ Just because there are statistically fewer children suffering in the United States as compared to other countries does not obviate the problem of individual children's suffering in the United States. The second is that the privilege of economic and political stability underlying children's positive outcomes in developed, industrialized countries like the United States is often built on the unacknowledged, exploitative socio-economic behaviors of global actors. ${ }^{39}$ Supposing children in the United States have good outcomes-without taking into account the larger context explaining how they have a disproportionate share of resources as compared to the rest of the world's children-could easily lead one to mistake positive outcomes in the United States as a result of individual, national, or even parental merit, rather than a general distribution issue. What statistician and writer Nassim Taleb calls the "pull of the sensational" 40 is another explanation for the United States's inactivity relative to children's interests generally. He offers examples of individual, sensational anecdotes that generate popular interest and an outsized media effect, when simultanesouly,there are many enduring worse suffering who are ignored in favor of the sensational story. ${ }^{41}$ He provides the example of an Italian toddler who fell

36. See Ed Bates, History, in International Human Rights Law 27-28 (Daniel Moeckli, Sangeeta Shah \& Sandesh Sivakumaran eds., 2d ed. 2014); Jack Donnelly, The Relative Universality of Human Rights, 29 Hum. RTs. Q. 281, 291 (2007).

37. See, e.g., Alston, supra note 16; see also Children, United Nations, https:// www.un.org/en/sections/issues-depth/children/index.html [https://perma.cc/C7G6LMWF] (reporting children's outcomes worldwide); The State of the World's Children 2019 Statistical Tables, UNICEF (Oct. 2019), https://data.unicef.org/resources/dataset/ sowc-2019-statistical-tables/ [https://perma.cc/HKK5-DZN3] (providing an interactive table that allows users to select the United States as a country to analyze in comparison to a region; although the measures for many outcomes exceed the outcomes for the rest of the global population, that does not obscure the reality that a percentage of children in the United States continues to suffer poor health and social outcomes).

38. See, e.g., Alston, supra note 16.

39. See generally Daron Acemoglu \& James A. Robinson, Why Nations Fail: The Origins of Power, Prosperity, And Poverty (2012) (exploring how past and present political and economic institutions, and colonialism in particular, have led nations to divergent outcomes).

40. Nassim Nicholas Taleb, The Black Swan: The Impact of the Highly IMPROBABLE 79-80 (2007).

41. Id. 
down a well in the 1970s. ${ }^{42}$ The popular imagination was caught in the drama of the child's rescue, but there was no similar outcry about the children caught in the Lebanese civil war, which involved car bombs being detonated in the Christian portion of Beirut. ${ }^{43}$

Other mistaken beliefs are much more difficult to tackle. There have already been three decades of analysis and persuasive writing aimed at correcting misperceptions about the CRC's nature and character. ${ }^{44}$ Despite all the writing and rhetoric, no matter how persuasive and compelling, no successful national movement to formally ratify the CRC has emerged. Ironically, the United States proposed several of the provisions in the $\mathrm{CRC},{ }^{45}$ becoming a key influencer in the normative vision of the CRC. This was much to the dismay of feminist and post-colonial critics who saw such involvement as further solidifying the United States's heteronormative, patriarchal vision into global legal conceptions of family. ${ }^{46}$ Nonetheless, the United States declined to ratify the CRC, even though nearly every other member country of the United Nations ratified it. ${ }^{47}$ One might draw the conclusion that the United States wished to make certain there was no misunderstanding about where it stood with regard to ratification. ${ }^{48}$ When the United States ratified the OPAC and OPSC of the CRC, it did so with an express provision allowing itself to ratify the OPs without ratifying the general Convention. ${ }^{49}$

The United States provided multiple proposals that appeared in the final version of the CRC, ${ }^{50}$ and yet the United States went on to oppose language that would have "referred to the CRC as the most authoritative expression of children's rights." ${ }^{11}$ Jonathan Todres

42. Id.

43. $I d$.

44. See, e.g., Didier Reynaert, Maria Bouverne-de-Bie \& Stijn Vandevelde, AReview of Children's Rights Literature Since the Adoption of the United Nations Convention on the Rights of the Child, 16 CHILDHOOD 518, 518 (2009).

45. See Cynthia Price Cohen, Role of the United States in Drafting the Convention on the Rights of the Child: Creating a New World for Children, 4 LOY. PoverTy L.J. 9, 26 (1998).

46. See generally Frances Olsen, Children's Rights: Some Feminist Approaches to the United Nations Convention on the Rights of the Child, 6 INT'L J. L. \& FAM. 192 (1992); Martha Minow, Rights for the Next Generation: A Feminist Approach to Children's Rights, 9 HARv. WOMEN's L.J. 1, 2 (1986).

47. United Nations Convention on the Rights of the Child, Nov. 20, 1989, No. 27531, 1577 U.N.T.S. 3 (showing current treaty ratification status; the United States is the only country on the list not to have ratified).

48. Luisa Blanchfield, The United Nations Convention on the Rights of the Child, Cong. Rsch. SERv. 1, 4-5 (Apr. 1, 2013), https://fas.org/sgp/crs/misc/R40484.pdf [https://perma.cc/RS4G-G9MB].

49. Treaty Doc 106-37, 106th Congress 2d Session, v (2000); Consideration of Reports Submitted by States Parties Under Article 8 (1) of the Optional Protocol to the Convention on the Rights of the Child on the Involvement of Children in Armed Conflict, II A(1)(a)(11), U.N. Doc. CRC/C/OPAC/USA/3-4 (Sept. 15, 2016).

50. Todres, supra note 6, at 19.

51. Id. at 19 n.1. 
considered why the United States, as "one of the authors of the CRC," was then "the only remaining country that actively opposes adoption of the CRC." 52 Todres identifies and critiques the reasons presented for non-ratification, focusing primarily on concerns about threats to national sovereignty and parents' rights. ${ }^{53} \mathrm{He}$ also notes that the root of resistance to the CRC is the "concern that the CRC is 'anti-parent' and will undermine the role of parents in raising their children." 54 The critique about parent-child relationships is a layered problem because it does not simply involve a political obstacle, but a moral and religious component, as well. In the United States, parental rights are deeply tied to religious education, and a suspicion of governmental interference in family sexual privacy cases persists. ${ }^{55}$

The patchwork of cases governing family sexual privacy can be as narrowly construed as prophylactic use for family planning or as broadly encompassing as marriage equality rights for sexual minorities. One has only to look at the current staple of popular family law casebooks ${ }^{56}$ used in United States law schools to see the wide variety of cases that make up the canon of family sexual privacy cases. Griswold $^{57}$ and Eisenstadt ${ }^{58}$ are famous contraceptives cases that are typically taught to establish foundational principles, such as the sanctity of the bedroom, when referring to the state's reluctance to regulate sexual activity for married and unmarried couples. ${ }^{59}$ On the other end of the spectrum, the 2015 Obergefell case finally settled the question of marriage equality for same-sex couples. ${ }^{60}$ In between those poles are cases about the rights of parents to educate children, such as Meyer and Pierce, which include an implicit recognition that parents have the

52. Id. at 19 .

53. Id. at $20-30$.

54. Id. at 20.

55. See generally James G. Dwyer, Parents' Religion and Children's Welfare: Debunking the Doctrine of Parents' Rights, 82 CAL. L. REv. 1371 (1994) (critiquing parents' rights, particularly when religious values are elevated above children's rights).

56. See generally John E.B. Myers, Experiencing Family Law (2013); Douglas E. Abrams, Susan V. Mangold \& Sarah H. Ramsey, Children and the Law: Doctrine, Policy, and Practice (6th ed. 2017); D. Kelly Weisberg, Modern Family Law: Cases and Materials (7th ed. 2020); Leslie Harris, Lee E. Teitelbaum \& June R. Carbone, Family Law (5th ed. 2014); Ann Laquer Estin, Domestic Relationships: A Contemporary Approach (1st ed. 2013); Walter Wadlington, Raymond C. O'Brien \& Robin Fretwell Wilson, Domestic Relations: Cases and Materials (8th ed. 2017); Robert H. Mnookin \& D. Kelly Weisberg, Child, Family, and State: Problems and Materials on Children and the Law (7th ed. 2014); James Dwyer, Family Law: TheOretical, Comparative, and Social Science Perspectives (2012); Judith Areen et al., Family Law: Cases and Materials (7th ed. 2019).

57. Griswold v. Connecticut, 381 U.S. 479 (1965).

58. Eisenstadt v. Baird, 405 U.S. 438 (1972).

59. See Craig A. Bowman \& Blake M. Cornish, Note, A More Perfect Union: A Legal and Social Analysis of Domestic Partnership Ordinances, 92 Colum. L. Rev. 1164, 1183 n.94, 1197 (1992).

60. See Obergefell v. Hodges, 576 U.S. 644, 680-81 (2015). 
right to have children. ${ }^{61}$ In other words, Meyer and Pierce are flexible cases that apply a narrow construction limited to educational rights to very expansive views that parents have the fundamental right to have children and raise them as they see fit, without unwarranted state intervention. ${ }^{62}$ This quick sketch-highlighting the basic contours of constitutionally protected parents' rights to the having and raising of children with the built-in presumption that parents act in the best interest of their children ("BIOC") ${ }^{63}$-is the groundwork for resistance to perceived state interference or disruption of parental rights. ${ }^{64}$ Any interference from the state, particularly for intact families that have little-to-no oversight or regulation by the state, tends to be perceived as an infringement of parents' privacy rights. Relatedly, the free exercise of religion and the privacy rights extended to parents in the upbringing of children protect families who observe religious beliefs that eschew modern medical intervention. ${ }^{65}$

In the space between protecting children from harm and providing greater protection to families lies the persistent reality that family members, at times, pose the largest threat to children. ${ }^{66}$ Violence against children, the exploitation of children for sex, labor, and/or organs, and other harmful practices oftentimes happen because of external pressures on families and their communities. ${ }^{67}$ Despite the reality that family members' actions may warrant intervention between parents and children, Todres argues that there is a misperception of the $\mathrm{CRC}$ as an intervention tool for the government to interfere between

61. See Meyer v. Nebraska, 262 U.S. 390, 399 (1923); Pierce v. Soc'y of the Sisters of the Holy Names of Jesus \& Mary, 268 U.S. 510, 534-35 (1925).

62. See Meyer, 262 U.S. at 399; Pierce, 268 U.S. at 534-35.

63. Troxel v. Granville, 530 U.S. 57, 89-90 (2000) (Stevens, J., dissenting) ("[O]ur substantive due process case law includes a strong presumption that a parent will act in the best interest of her child ....").

64. Skinner v. Oklahoma ex rel. Williamson, 316 U.S. 535, 541 (1942) (characterizing procreation as "one of the basic civil rights of man"). As Justice Brennan noted in Eisenstadt v. Baird, 405 U.S. 438, 453 (1972) (internal citations omitted): "[i]f the right of privacy means anything, it is the right of the individual, married or single, to be free from unwarranted governmental intrusion into matters so fundamentally affecting a person as the decision whether to bear or beget a child."

65. See generally David Orentlicher, Law, Religion, and Health Care, 8 U.C. IRvine L. Rev. 617, 622-25 (2018); Misty Boyer, Death by Religious Exemption: Parents Refusing Their Child Necessary Medical Treatment Based upon Their Own Religious Beliefs - Should States Endorse a System That Denies Necessary Medical Treatment to Children?, 4 Whittier J. Child \& Fam. Advoc. 147, 150 n.15 (2004); Jennifer L. Hartsell, Mother May I . . Live? Parental Refusal of Life-Sustaining Medical Treatment for Children Based on Religious Objections, 66 TenN. L. REv. 499, 501-02 (1999).

66. DeShaney v. Winnebago Cty. Dep't of Soc. Servs., 489 U.S. 189 (1989) (explaining how a father abused his four-year-old child over time, despite awareness of the abuse by state actors, resulting in traumatic head injuries so severe that the child succumbed to a coma and suffered significant brain damage).

67. Int'l Programme on the Elimination of Child Labour, Int'l Labour Org., Child Trafficking: The ILO's Response Through IPEC 3 (2007). 
parents and children. ${ }^{68}$ Todres' 2006 observation suggests that the stickiness of legal ideas about children should not be underestimated. For example, in 1986, Martha Minow argued that an obstacle to consistent legal treatment has been due to "legal conceptions affecting children-legal conceptions insensitive to the relationships children have and those they need." ${ }^{69}$ Her call to action includes "develop[ing] a perspective on children's rights that refrains from comparing the abilities of children and adults and instead addresses their mutual needs and connections." 70 Years later, developing an approach to the law that is mutually reinforcing of adults' and children's interests has yet to be realized. Todres continues the fight and builds on Minow's argument by advocating for the CRC's ratification and its capacity to take into account children's rights vis-à-vis their relationships to parents, family members, other adults, and the state. ${ }^{71}$ According to Todres, the CRC heightens family protection, giving parents greater protection to raise their children and protecting children's rights ${ }^{72}$ from unwarranted state intervention. Todres' critique of the misperceptions that the CRC undermines parental rights "demonstrates the considerable lengths to which the CRC goes to emphasize the great value that it places on the rights and duties of parents in raising their children." 73

The CRC is clear that it "does not allow parents to act without impunity toward their children." 74 Just as in the United States domestic legal system, there are laws and policies in place for the state to intervene when parents harm their children, so too the CRC "obligates states to act to protect children" from harm. ${ }^{75}$ Tragically, in some parts of the United States it is the state that currently poses one of the greatest dangers to children. The state separated parents from children at national borders in detention camps ${ }^{76}$ and failed to correct child removal rates that unfairly impacted low-income status and racial minority families. ${ }^{77}$ The resistance to ratification sounds in neoliberalism, balking at the idea the state will be required to act as a duty bearer to rights holders. DeShaney stands as a tragic example of the underlying fear of state responsibility to children as a positive, ac-

68. See Todres, supra note 6 , at 20.

69. Minow, supra note 46, at 2.

70. $I d$.

71. See Todres, supra note 6 , at 31 .

72. See id. at 20-27.

73. Id. at 27.

74. Id.

75. $I d$.

76. See Ron Nixon, U.S. Loses Track of Another 1500 Migrant Children, Investigators Find, N.Y. TIMES (Sept. 18, 2018), https://www.nytimes.com/2018/09/18/us/politics/us-migrant-children-whereabouts-.html [https://perma.cc/LP75-F8ZY].

77. Children and Adolescents in the United States' Adult Criminal Justice System, InTER-Am. COMm'N ON Hum. RTs. 9, 70-71 (2018), http://www.oas.org/en/iachr/reports/pdfs/Children-USA.pdf [https://perma.cc/YK95-P5FB]. 
tive duty. ${ }^{78}$ In DeShaney, the child and his mother claimed that by failing to remove him from his father's care after warnings of physical abuse, the state violated the child's "liberty interest in bodily integrity."79 The Court's response is representative of the defensive posture of U.S. jurisprudence. Rather than affirmatively act to protect citizens - in this case, children - the law is a tool to protect the state from overreaching into individual rights and liberty interests. Notably,

The Clause is phrased as a limitation on the State's power to act, not as a guarantee of certain minimal levels of safety and security; while it forbids the State itself to deprive individuals of life, liberty, and property without due process of law, its language cannot fairly be read to impose an affirmative obligation on the State to ensure that those interests do not come to harm through other means. ${ }^{80}$

Since the state is not a duty bearer with a responsibility to act affirmatively to protect children, the Court held that there was no violation of constitutional law: ${ }^{81}$ "a State's failure to protect an individual against private violence generally does not constitute a violation of the Due Process Clause." ${ }^{82}$ Now, more than ever, the state's seemingly unlimited power and its ability to wrongfully intervene in families militates toward adopting the CRC. The misperceptions about the state's ability to intervene, being increased by ratification of the CRC, further the state's ability to create the conditions for losing thousands of children, preventing families from ever reuniting, and subjecting children to sexual and physical assault and other traumatic experiences in institutions, foster care, ${ }^{83}$ and detention centers ${ }^{84}$ with impunity.

78. See DeShaney v. Winnebago Cty. Dep’t of Soc. Servs., 489 U.S. 189 (1989).

79. Id. at 191.

80. Id. at 195 .

81. Id. at 202.

82. Id. at 197.

83. Foster Care Statistics 2018, Child.'s Bureau (May 2020), https:// www.childwelfare.gov/pubPDFs/foster.pdf [https://perma.cc/DCV9-WJ5C]; Ron Haskins, Driving Better Outcomes for Children in Foster Care, Brookings (Feb. 14, 2019), https://www.brookings.edu/blog/up-front/2019/02/14/driving-better-outcomesfor-children-in-foster-care/ [https://perma.cc/2FEB-GYY7] (noting that approximately $13 \%$ of 442,995 children placed in foster care in 2017 "were placed in congregate care ...., where youth experience poorer outcomes than those in family-care placements").

84. See Nixon, supra note 76; Cynthia Pompa, Immigrant Kids Keep Dying in CBP Detention Centers, and DHS Won't Take Accountability, ACLU (June 24, 2019, 12:45 PM), https://www.aclu.org/blog/immigrants-rights/immigrants-rights-and-detention/ immigrant-kids-keep-dying-cbp-detention [https://perma.cc/455T-FD6S]; Associated Press, Migrant Kids Split at Border Were Harmed in Foster Care, Claims Say, USA TODAY, https://www.usatoday.com/story/news/politics/2019/08/16/immigrant-childrenseparated-border-abused-foster-care-claims/2027970001/ (Aug. 16, 2019, 7:33 AM) [https://perma.cc/U46V-JW89]; Christopher Sherman, Martha Mendoza \& Garance Burke, US Held Record Number of Migrant Children in Custody in 2019, Associated Press (Nov. 12, 2019), https://apnews.com/015702afdb4d4fbf85cf5070cd2c6824 [https:/ /perma.cc/9XSU-2QWR]; Applied Rsch. Ctr., Shattered Families: The Perilous Intersection of Immigration Enforcement and the Child Welfare System, RACE FORWARD 1, 
The second major threat is to United States sovereignty should it become beholden to other countries' oversight through the ratification of international human rights treaties. ${ }^{85}$ This fear is based on a misperception that ratification of international human rights treaties authorizes enforcement beyond self-reporting compliance with treaty mandates and receiving commentary from other treaty parties. ${ }^{86} \mathrm{Re}$ latedly, there are fears connected to the United States's dual system of federal and state laws ${ }^{87}$ which is designed to allow individual states within the country to manage local concerns, like the health, welfare, and safety of their citizens. Opponents of the CRC refer to the United States's laws about capital punishment as an example of ceding local state governance powers to the federal government. ${ }^{88}$ Federal government powers end where the CRC is believed to begin, creating a complicated relationship between a national, federal governmental body dictating that the state should embrace an international standard for laws and policies related to children and their rights. Even if the federal government, through its executive or legislative branch, were to ratify the treaty, it would be left to the individual states to adopt and implement the treaty mandates and thus would not undermine or threaten local state governance. ${ }^{89}$ More importantly, the United States could ratify the CRC without upholding every mandate, as there are "limited enforcement mechanisms" built into the CRC. ${ }^{90}$ One way the CRC's opponents in the United States have avoided the problem of being an author who is not beholden to laws made for all other global citizens is to emphasize the narrative that the treaty does not need to be ratified because the existing legal scheme in place-the United States Constitution and individual state constitutions-adequately protects children's rights in the same or better manner than the CRC purports to do. ${ }^{91}$ By either justifying non-ratification with a federalism concern or by claiming that the existing United States legal protections are the equivalent of the CRC, American refusal to submit itself as an equal international actor persists. Another issue between aspiration and realization when it comes to ratifying the CRC is the critiques levelled at the instrument. Whether it stems from philosophical concerns about the CRC's welfarist conception of children's rights or from feminist concerns that the CRC will be another tool of

43 (Nov. 2, 2011), https://www.raceforward.org/research/reports/shattered-families [https://perma.cc/AN7M-ZJRP] [hereinafter Shattered].

85. Todres, supra note 6 , at 20.

86. Id. at 28.

87. Id. at 29.

88. Id.

89. Id.

90. Id. at 30 .

91. Woodhouse, supra note 9, at 61 (acknowledging that children in the United States enjoy some rights, but the United States is no longer a leader in protecting children's rights as compared to nation-states that implement the CRC). 
women's oppression, it is useful to consider whether those critiques are enough to justify refusal to ratify altogether. One critique is that it is impossible to know what children want as they are incapable of articulating their interests coherently. ${ }^{92}$ There are developmental realities that make it difficult to argue that children can process, let alone articulate, their own self interests. The physical limitation of an inability to predict and process future consequences from present choices is just one aspect of assessing children's capacity for holding and exercising rights. In United States domestic relations cases, particularly in child custody determinations, the norm is to prevent children from speaking directly in court. ${ }^{93}$ The psychic toll of being asked to choose between parents or risking vulnerable children's exploitation if there are violent or abusive behaviors in the parent-child relationship are real concerns that are met with in camera interviews, third-party expert witnesses, and other forms of children's representatives such as Guardian ad Litem. ${ }^{94}$

Another important critique is the unintentional negative outcomes for women that come at the expense of helping children. ${ }^{95}$ Women's fates have been intertwined legally with children's for so long that it is still difficult to parse out rights, and there is a risk that these rights do not flow in the same direction..$^{96}$ Human rights laws have been used to "improve, and perhaps already have improved the lives of women." 97 However, the framework that benefits some women's lives has been "dominated by men" with the result being a furtherance of the "international subordination of women." 98 While certainly the fates of women, often caregivers to children, are intertwined with children's, their suites of rights are not always in alignment. ${ }^{99}$ In addition to domestic and familial concerns, there are other implications because of the nature of a male-dominated legal framework. ${ }^{100}$ A prime example of this point is OPAC, ${ }^{101}$ but there is a question about the strength of the prohibition against child marriages. The practice of training and

92. But see David William Archard, Children's Rights, Stan. Encyclopedia PHIL. (Winter 2018), https://plato.stanford.edu/archives/win2018/entries/rights-children/ [https://perma.cc/9TZU-WNFW] ("Similarly the making by a child of a poor choice is not conclusive evidence of her general incapacity to choose for herself. Wise adults can occasionally make stupid decisions just as fools sometimes get it right.").

93. See Tara Lea Muhlhauser, From "Best" to "Better": The Interests of Children and the Role of a Guardian Ad Litem, 66 N.D. L. REv. 633, 637-38 n.22 (1990).

94. Id. at 636.

95. Olsen, supra note 46, at 193.

96. $I d$.

97. Id.

98. Id.

99. Id.

100. Id. at 192 .

101. Trevor Buck, 'International Criminalisation and Child Welfare Protection': The Optional Protocol to the Convention on the Rights of the Child, 22 CHILD. \& Soc'y 167, 168 (2008). 
deploying child soldiers largely impacts boys, and child marriages largely impact girls. ${ }^{102}$

The OPSC focuses primarily on prohibiting the sale of children for sex and/or organs. ${ }^{103}$ The Committee on the Rights of the Child, when reporting about the implementation of the OPAC and OPSC, included child marriage when children were traded for money. ${ }^{104}$ The Committee noted that Syrian Arab Republic communities were engaged in the "practice of early and forced marriage and temporary marriages involving girls as young as [twelve] years who are given in marriage in exchange for money." 105 In addition to covering child marriage, even if not explicitly in its substantive content, the OPSC in practice should provide stronger forms of criminalization for wrongdoers and protection for children. ${ }^{106}$ Based solely on the amount of attentiveness to women's and children's rights, child marriage, and other related oppressive practices, such as female genital mutilation, ${ }^{107}$ one might conclude that there is widespread consensus among world leaders about the seriousness of harmful practices that impact women and children. Despite attentiveness in drafting significant conventions and treaties to address harmful practices that impact women and children, there continues to be a significant gap between ratification and domestication. ${ }^{108}$ This gap is due, in part, to reservations that states make to conventions and treaties. ${ }^{109}$ Per the Vienna Convention on the Law of Treaties ("VCLT"), ${ }^{110}$ a sort of civil procedure "handbook" for the interpretation of international human rights agreements, a reservation is "any statement ... that aims to restrict-either totally or partiallythe scope of the application of a given treaty," 111 unless the reservation is "contrary to the object and purpose of the relevant treaty," 112 which is prohibited. The use of reservations is contested as the excep-

102. Olsen, supra note 46, at 194.

103. Buck, supra note 101 , at 168-70.

104. Id. at 174.

105. Id.

106. Id. at 168 (suggesting that "the Protocol's implementation, though enhancing international criminalisation of perpetrators, provides far weaker support for the welfare protection of child victims").

107. Nazila Ghanea, Women and Religious Freedom: Synergies and Opportunities, U.S. COMm'N ON INT'L Religious Freedom 1, 7 (2017), https://www.uscirf.gov/sites/ default/files/WomenandReligiousFreedom.pdf [https://perma.cc/J97H-7H8M] (illustrating, through a chart, the most "prevalent and well-documented of the harmful practices" per the CRC and CEDAW that includes female genital mutilation, child and/or forced marriage, polygamy, "honor" killings, and dowry-related violence).

108. Id. at 1.

109. $I d$.

110. Vienna Convention on the Law of Treaties art. 2(d), May 23, 1969, 1155 U.N.T.S. 333.

111. Başak Çali \& Mariana Montoya, The March of Universality?: Religion-based Reservations to the Core UN Treaties and What They Tell Us About Human Rights and Universality in the 21st Century 10 (2017).

112. Id. 
tions in some cases threaten to obviate the rule altogether. ${ }^{113}$ Francoise Hampson, submitting a report to the Economic and Social Council of the United Nations, observed that the VCLT "regime [favors] the reserving State." 114 There is no clear oversight or governing body that determines whether a reservation is incompatible with a treaty's object and purpose. ${ }^{115}$ If there are no objections from other member states within a prescribed amount of time, the silence is taken as consent to the reservation. ${ }^{116}$ Some treaty parties may not object to reservations that states make, even if they negatively impact women and children, in the hope of moving closer to the overarching goal of persuading more states to ratify a convention. Even with the potentially ineffective bar against reservations that are "incompatible with the object and purpose of the treaty," upholding women's and children's human rights obscures the reality that many women and children continue to be subject to human rights violations. ${ }^{117}$ Because child marriage practices are considered a part of cultural and/or religious practices, and "religion is among the asserted grounds for women's rights violations, though this invocation of religion may well be covering a range of socioeconomic, traditional, political, and other objectives for states and have a tenuous relationship with 'religion' as such," the end result is that other rights and interests are prioritized over women's and children's rights. ${ }^{118}$

After fighting so long for the liberation of and rights for women, advocating for children's rights is critical. As an example, one can see that rights may not flow seamlessly together in cases where women and children are economically vulnerable. For years in the United States, heterosexual couples have specialized in the division of labor; generally speaking, men have worked outside the home, and women have provided the bulk of care work for children and the elderly. ${ }^{119} \mathrm{~A}$ recent study dismayingly showed that in several decades, the number of women opting out of the workplace to provide care work has remained steady, despite economic pressures and increased opportunities for school and work. ${ }^{120}$ Having more women stay home to provide

113. Francoise Hampson, Specific Human Rights Issues: Reservations to Human Rights Treaties (Comm'n on Hum. Rts., Final Working Paper E/CN.4Sub.2/2004/42, 2004).

114. Id. at 9 .

115. Id. at 7 .

116. $I d$.

117. Id. at 2 .

118. Ghanea, supra note 107 , at 7-8.

119. Charlotte J. Patterson, Erin L. Sutfin \& Megan Fulcher, Division of Labor Among Lesbian and Heterosexual Parenting Couples: Correlates of Specialized Versus Shared Patterns, 11 J. Adult Dev. 179, 179 (2004).

120. Leila Schochet, The Child Care Crisis is Keeping Women Out of the Workforce, Стr. Ам. Progress (Mar. 28, 2019, 8:00 AM), https:// www.americanprogress.org/issues/early-childhood/reports/2019/03/28/467488/childcare-crisis-keeping-women-workforce/ [https://perma.cc/6LYB-9JLL]. 
childcare means that women are often a child's primary caregiver. ${ }^{121}$ In the event of a divorce, women without work experience or educational attainments are at a distinct disadvantage. ${ }^{122}$ If there is no equalizing of pay and accounting for unremunerated care work for the marital community, women are often left in dire economic states. ${ }^{123}$ To then invest in children the right to state their preferences or interests for a parental caregiver is fraught with difficulty. Another related concern is that of reproductive rights. In the United States, there has been an ongoing tension between women's bodily autonomy rights and the state's interest in protecting fetal life. ${ }^{124}$ To press the question further in the case of children's rights, the spectre of children's rights overcoming women's rights, particularly when it is unclear that there is any consensus on which rights and interests should be paramount in abortion cases, gives pause.

Although one might believe that these critiques militate toward non-ratification of the CRC, that would be a mistake. Thoughtful critics acknowledge beneficial aspects of the CRC and then seek to improve it. For example, John Eekelaar's critique of welfarist approaches ${ }^{125}$ to children's rights is centered on the dilemma of the question: "[I]f someone has the right to determine my welfare, do I have rights in any meaningful sense?"126 Currently, in the United States, adults have built domestic relations legal doctrine and practice on determinations of "the best interest of the child" made by interested adults, rarely by the children themselves. ${ }^{127}$ Nevena VučkovićSahovic notes that "the concept of the best interest of the child is well known by professionals that work with or for children, the notion is very difficult to define, and it has been the object of virulent criticism, ranging from being called a hollow shell to the vase that one fills as one pleases." ${ }^{28}$ At times, courts may appoint a Guardian ad Litem to speak on behalf of a child's interests but often with a limited ability to determine outcomes for the child at bar. ${ }^{129}$ Relying solely on parents' conformity with the BIOC standard is fraught in legal systems that

121. $I d$.

122. Derek A. Kreager et al., Women's Education, Marital Violence, and Divorce: A Social Exchange Perspective, 75 J. Marriage \& FAm. 565, 565 (2013).

123. Id. at 567.

124. See Roe v. Wade, 410 U.S. 113 (1973).

125. See John Eekelaar, The Importance of Thinking That Children Have Rights, 6 INT'L J.L. \& FAM. 221, 221 (1992).

126. Id. at 223.

127. Jon Elster, Solomonic Judgements: Against the Best Interest of the Child, 54 U.

Chi. L. Rev. 1, 5 (1987).

128. See Nevena Vučković-Šahović, Childhood and International Rights of the Child, in The Rights of The Child in International Law (Nevena VučkovićŠahović, Jaap E. Doek \& Jean Zermatten eds., 2012).

129. Muhlhauser, supra note 93, at 634-35. 
grant strong parental rights to the control and custody of children. ${ }^{130}$ The idea of strong parental rights, as opposed to recognizing children's rights separate from their parents' rights, persists. Harry Brighouse and Adam Swift argue that the language of children's rights and parental rights is inappropriate in a loving relationship. ${ }^{131}$ Instead, in Brighouse and Swift's model, parental rights are conceived as "service to the governed," aligning children's interests with parents' loving governance. ${ }^{132}$ In contrast, Eekelaar's vision of children's rights arising from a relational practice rather than a moral obligation presents rights as something philosophically substantive rather than a product of external deliberations about another person's rights. ${ }^{133}$ If a parent may perceive her actions toward non-human life in terms of moral obligation without conceding that such life has rights, except perhaps metaphorically, so too could she view her actions toward a child (without rights) in terms of moral obligation, not legal duty. "Righthood" can only be realized when sufficient duties or powers are conferred on others. So, while owing duties to others does not necessarily imply that the others have rights (except in a formalistic sense), no one can have rights unless the claims that they embody are protected by duties on others. ${ }^{134}$ Eekelaar's conception of children as rights holders reinforces the intimate tie between parents and children's other caregivers as having a duty to protect rights as a method for realizing rights. ${ }^{135}$ There is no conflation of the child's rights with a legal or social presumption that parents' and children's interests align simply because the parent-child relationship exists. ${ }^{136}$

Rather, Eekelaar advocates for children's rights as an expression of "what children say" that "must therefore lie at the root of any elaboration of children's rights." 137 This might be frightening or unrealistic to adults who fear that children's views are "[colored] by ignorance or parental influence." 138 Thus, Eekelaar's granular critique of the CRC's welfarist or protective approach to children's rights is that there is an assumption that adults will act in furtherance of children's rights, "not in derogation of the rights." 139 The radical reform that Eekelaar suggests would be to recognize children's humanity as the basis for their rights and ability to make claims, so that, "from the moment of their birth continuously into adulthood," humans would

130. See Barbara Bennett Woodhouse, "Who Owns the Child?": Meyer and Pierce and the child as Property, 33 WM. \& MARY L. ReV. 995 (1992).

131. Adam Swift \& Harry Brighouse, Family Values: The Ethics of ParENT-Child Relationships (2014).

132. Id. at 19

133. Eekelaar, supra note 125 , at 228.

134. Eekelaar, supra note 125 , at 227.

135. Id. at 228.

136. See generally id.

137. Id. at 228.

138. $I d$.

139. See id. at 233. 
have rights. ${ }^{140}$ Notwithstanding the room for improvement in conceptualizing children's rights vis-à-vis their humanity, Eekelaar's critique assumes that the CRC is the baseline for recognizing children's rights and that reform should take place after the ratification and implementation of the CRC. ${ }^{141}$ Eekelaar's critique seeks to imagine improvements to the existing protection of children by first ratifying and next tailoring the application as an ongoing project. ${ }^{142}$ However, viewing the CRC as a fixed, static set of rules that must be ratified-ratification that would suddenly provide standardized legal protection to children-seems to have a stranglehold on those devoted to formal, positive law. It is critical to understand that the CRC, like many laws, is flexible and capacious in its ability to adjust to the individual circumstances of various children while also focusing on the humanity of all children. In fact, this is much like Vučković-Šahović's characterization of the standard BIOC as a "rule in itself" 143 that further lends itself to becoming a "principle of interpretation" and an "indeterminate legal concept which should be specified by practice." 144 In this way, the rule that one must first take a child's interests into account as a "primary consideration" before one can use the BIOC concept to discover the specific way in which it applies to the child is different than a fixed law. This approach reflects a tailoring of law to the subject at bar and the dynamism of applying law to humans, not ideas or things. Imagine that a judge has to determine whether a child should be removed from her home. The baseline consideration, that parents act in the best interest of their children, may not ultimately protect children and represent the child's interest as primary. ${ }^{145}$

Similarly, feminist scholar Frances Olsen's critique acknowledges the benefits of the CRC and voices concerns as a method for improving the CRC to extend benefits to more people, not to discard the project entirely. ${ }^{146}$ Olsen's critique of the CRC acknowledges that, while there may be beneficial aspects to ratifying the CRC, there is also the risk that the CRC could "be used to control and confine women."147 There has been a connection between limiting women's rights in the furtherance of better outcomes for children, particularly in the areas of reproductive rights and caregiving duties. ${ }^{148}$ As a voice of caution, Olsen raises concerns that are not only valid, but that feed directly into the conversations that should be included in protecting children from sex trafficking, exploitation, and pornography. Again,

140. Id. at 234.

141. Id. at 231-34.

142. See id.

143. See Vučković-Šahović, supra note 128, at 97.

144. $I d$. at 98 .

145. Cf. DeShaney v. Winnebago Cty. Dep't of Soc. Servs., 489 U.S. 189 (1989).

146. See generally Olsen, supra note 46.

147. Id. at 198.

148. Id. at $198-99$. 
an ongoing critique of patriarchal systems is not a justification for non-ratification of any international human rights convention, but a guiding voice toward recognition of women as fully human.

\section{Progress in the United States?}

Against a backdrop of the United States's historic reluctance to ratify the CRC, as compared to the rest of the global community, this Part provides a brief overview of the state of children in the world, which justified the creation and use of a legal tool like the CRC to authorize stronger legal protection for children. Minow's case for the CRC is animated by the need for a more consistent treatment of children. ${ }^{149}$ She posits that "the inconsistent legal treatment of children stems in some measure from societal neglect of children. The needs and interests of children, difficult enough to address when highlighted, are too often submerged below other societal interests. The dominance of these other interests helps to explain the inconsistent treatment of children." 150 There is plenty of room for optimism that the United States's recalcitrance to participate more actively in supporting international human rights may be waning. With the internet, global travel, and greater global connectedness, the possibilities for change exist and can be used more forcefully than before. Moreover, the United States is not immune from pressure generated domestically and internationally to fight the spread of child trafficking, sexual exploitation, pornography, and involvement in armed conflict. ${ }^{151}$ Unlike current forms of domestic legal protection in the United States that focus on children's rights only through the lens of parents and the state (usually in criminal and welfare contexts), the CRC recognizes that all children are rights holders because they are human and that the nature of their rights is unique because of their status as children.

Vučković-Šahović argues the CRC is a critical human rights convention because "the definitions of fundamental rights of the child [we]re provided for the first time in history and for the first time in international law, [a] treaty contain[ed] a universally accepted definition of the child." 152 The CRC is ideally situated to provide a better, more durable legal framework for protecting the rights of all children, but especially those who are otherwise outside the scope of domestic legal protections that tend to be in place for children who enjoy class, racial, language, religious, sexual-orientation, gender-identity, and immigration-status privilege. The CRC "enshrines all main traditional groups of human rights: economic, social, cultural, political and

149. Minow, supra note 46, at 1-2.

150. Id. at 6 .

151. See generally S. Exec. ReP. No. 107-4 (2002).

152. See Vučković-Šahović, supra note 128 , at 48. 
civil." ${ }^{153}$ There is ample evidence that the children are not all right, which should renew motivation to act.

Domestically and abroad, children's situations and outcomes continue to be extremely disparate. David Lancey, author of The Anthropology of Childhood, notes that currently, "these are the best of times and the worst of times" for children. ${ }^{154}$ Children in highly developed, wealthy communities are more likely to have a surfeit of attention and resources, which results in them being overfed, having access to too much digital media, and having every moment programmed for them in a race to prepare for a successful adulthood. ${ }^{155}$ In contrast, the vast majority of the world's children suffer from a general lack of resources and attention, as evidenced by high rates of extreme poverty, food and shelter insecurity, lack of educational opportunities, various forms of exploitation, and the ongoing effects of natural disasters and other conflicts. ${ }^{156}$ In 2013, Special Rapporteur Gulnara Shahinian disclosed statistics about forced labor, noting the high numbers in each region and observing that women and children were particularly vulnerable to contemporary slavery since women often provide for children and are often restricted from education. ${ }^{157}$ Child soldiers continue to be recruited, despite the fact that most states ${ }^{158}$ ratified the OPAC, agreeing to not recruit children younger than eighteen years of age. ${ }^{159}$ The sexual exploitation of children is now understood to encompass the interlinked phenomenon of sex tourism, online sexual predation, child prostitution, children in underage marriages, ${ }^{160}$ and the rape and sexual assault of children as a weapon of war. ${ }^{161}$ In $2015,5.9$ million children under the age of five died from deaths that could have been

153. Id.

154. LANCY, supra note 12, at 24.

155. Id. at $26-29,72$.

156. Id. at $12-13,24$.

157. U.N. Hum. Rts. Council, Report of the Special Rapporteur on Contemporary Forms of Slavery, Including its Causes and Consequences, II 8, U.N. Doc. A/HRC/24/ 43 (July 1, 2013) (citing the International Labour Organization ("ILO") report about the prevalence of forced labor in regions and reasons behind higher rates of women and children in forced labor).

158. See generally Oona A. Hathaway, Do Human Rights Treaties Make a Difference?, 111 YALE L.J. 1935, 1976-77 (2002). At last count, 193 countries ratified the CRC. Id. There are some arguments that those that ratify the fastest are the likeliest to violate treaty norms the most egregiously. Id. However, there is a significant case to be made for states like the United States to ratify based on its global position and history of upholding treaty mandates that it does ratify. Id.

159. Children in Armed Conflict, supra note 4; OPAC Status, ChiLd Soldiers INITIATIVE, http://childsoldiersworldindex.org/opac-status [https://perma.cc/9577-4BVN].

160. Angela Hawke \& Alison Raphael, Offenders on the Move: Global Study on Sexual Exploitation of Children in Travel and Tourism 6, 10-11, 57 (2016), https://protectingchildrenintourism.org/wp-content/uploads/2018/10/ Global-Report-Offenders-on-the-Move.pdf [https://perma.cc/E6XS-T8MK].

161. Denis Mukwege, Nobel Peace Prize Laureate, Nobel Lecture (Dec. 10, 2018) (transcript available at The Nobel Foundation). 
preveted by affordable means of care or prevention, and nearly half of the world's extreme poor are children. ${ }^{162}$

In response to the human rights challenges that are uniquely challenging for children, the CRC seeks to intervene and focus attention on improving children's lives. ${ }^{163}$ As stated earlier, nearly all nationstates have formally ratified the CRC. ${ }^{164}$ The CRC is a stand-alone, yet complementary treaty that defines the rights held by children based on the core human rights treaties (e.g., the International Covenant in Civil and Political Rights; the International Covenant of Social, Economic, and Cultural Rights; and the Convention on the Elimination of All Forms of Discrimination Against Women). ${ }^{165}$ Children who live in states that have ratified and progressively implemented the CRC receive practical benefits as a cause of the implementation. Although opponents of ratifying the CRC might find traction in arguing that there are states that have ratified the CRC yet have failed to implement it, that discussion is outside the scope of this Article. Treaty ratification rates tend to be high without correspondingly high implementation rates ${ }^{166}$ but, at the very least, once formally accepted by a government, the treaty lays the groundwork for expressive lawmaking. ${ }^{167}$

International human rights treaties designed to protect children may be perceived as ineffective ${ }^{168}$ when measured quantitatively by ratification rates or on-the-ground evidence of implementation, capacity building, and enforcement of the human rights mandates. ${ }^{169}$ Rather, a positive view should be taken that treaties such as the CRC are valuable because they are expressive, providing the opportunity for important "position-taking" and norm setting that states can aspire to adopt and implement. ${ }^{170}$ Substantively, the CRC principles are the product of multiple constituencies working together to form a coherent framework for extending legal protection to children from multiple cultural and economic backgrounds. ${ }^{171}$ Viewing the CRC as a "tool, not a rule" 172 means that it is not a code that is simply dropped

162. The State Of The World's Children 2016: A Fair Chance For Every Child, UNICEF 10 (2016), https://www.unicef.org/media/50076/file/UNICEF_SOWC_2016ENG.pdf [https://perma.cc/54M5-4VQZ].

163. Children in Armed Conflict, supra note 4.

164. Hathaway, supra note 158, at 1935, 1977.

165. Children in Armed Conflict, supra note 4.

166. See Hathaway, supra note 158, at 1940, 1981; Emilie M. Hafner-Burton \& Kiyoteru Tsutsui, Justice Lost! The Failure of International Human Rights Law to Matter Where Needed Most, 44 J. PeAcE Rsch. 407, 409 (2007).

167. See Hathaway, supra note 158, at 2006.

168. See id. at 1956; Eric A. Posner, Martii Koskenniemi on Human Rights: An Empirical Perspective 5 (U. Chi. Pub. L. \& Legal Theory Working Paper No. 467, 2014).

169. See Hathaway, supra note 158, at 1940, 1956, 1989.

170. Id. at 2011; Vissing, supra note 2, at 80.

171. Revaz, supra note 3 , at 13.

172. Vissing, supra note 2 , at 80. 
on a state wholesale but is an ideological lodestar for creating solutions tailored for each state's particular circumstances while upholding universal human rights principles. ${ }^{173}$ To focus on the norm-setting value of international human rights treaties requires an in-depth discussion of norms (particularly as norms shift beliefs and/or behaviors) to distinguish norm-setting value from the valuation of laws as implemented behavior. ${ }^{174}$

After a formal legislative or executive ratification of a treaty, there is plenty of cover for groundswell activism and external, third-party actors to begin the work of implementation. ${ }^{175}$ Examples of groundswell approaches that have been successful are the adoption of human rights principles,${ }^{176}$ the increase of domestic prosecutions, ${ }^{177}$ and the use of peer countries to persuade treaty members to withdraw reservations to core human rights treaties. ${ }^{178}$ Groundswell approaches demonstrate that once new norms are accepted and begin to change a country's legal landscape, there is implicit authorization for domestic legal systems to begin implementation under color of law. ${ }^{179}$ Furthermore, there is evidence that advanced economic states like those of the European Union that have ratified and embraced the CRC, are already benefiting children. ${ }^{180}$ As Ursula Kilkelly notes, the European Court of Human Rights has made a "considerable contribution" to child law and policy across Europe by drawing on the provisions of the Convention on the Rights of the Child and other international childrens' rights standards and applying them to children's cases. ${ }^{181}$ Without the CRC, there would continue to be little law and policy from which to draw when making legal decisions about children. ${ }^{182}$ Currently, U.S. family law scholars, Douglas NeJaime, Clare Huntington, and Courtney Joslin, are working on a comparative social parenthood project comparing European and U.S. legal family ordering systems. ${ }^{183}$ In European systems, the CRC requires legal decision-makers to consider the BIOC at the outset of processes that will impact children. In comparison, the U.S. legal ordering system places emphasis

173. $I d$.

174. See Hathaway, supra note 158 , at 1941.

175. Id. at 1957.

176. Tamara Relis, Human Rights and Southern Realities, 33 Hum. RTs. Q. 509, 546 (2011).

177. Verónica Michel \& Kathryn Sikkink, Human Rights Prosecutions and the Participation of Rights Victims in Latin America, 47 L. \& Soc'y Rev. 873, 903 (2013).

178. ÇALI \& Montoya, supra note 111, at 34.

179. See Hathaway, supra note 158, at 1957.

180. Ursula Kilkelly, The Best of Both Worlds for Children's Rights? Interpreting the European Convention on Human Rights in the Light of the UN Convention on the Rights of the Child, 23 Hum. RTs. Q. 308, 326 (2001).

181. Id. at 308-09.

182. Id. at 311.

183. Interview with Douglas NeJaime, Professor of Law, Yale Law School (Nov. 25, 2020). 
on the parent-child relationship. ${ }^{184}$ There are positive signs of legislative reforms featuring a child-first approach, such as the changes made in the 2017 Uniform Parentage Act, that expressly use the BIOC test when considering parentage claims. ${ }^{185}$

If the United States ratifies the CRC, the greatest legal benefit that could redound to children is a conceptual shift toward recognizing children as rights holders because of their status as human children. ${ }^{186}$ Although there are forty-two articles that make up the CRC, Cris Revaz argues that the overarching legal framework of the CRC seeks to accomplish the following objectives: (1) implementing the BIOC standard for decisions or actions affecting the child; (2) eliminating discrimination against the child; (3) acknowledging the child has the right to survival and development in physical, spiritual, economic, educational, and all other aspects of the child's life; and (4) recognizing the child has a right to be heard and the right to freedom of expression. ${ }^{187}$ Importantly, at its root, the CRC recognizes that children are rights holders in their own right, ${ }^{188}$ despite the fact that they cannot exercise their rights without the assistance of adults and/or the state. ${ }^{189}$ The CRC can act as both a sword and a shield to advocate for greater protection from the state and to guard against an overly aggressive state. ${ }^{190}$ Balancing the need to obtain state protection from third parties, including at times parents and caregivers, with the mandate to also protect children from the state itself means that the CRC has to be flexible and capacious enough to properly balance competing interests. ${ }^{191}$

One measure of progress for children's rights advocates in the United States is the growth of non-government organizations ("NGOs") and think tanks that provide support, research, and funding for the protection of children's rights. ${ }^{192}$ NGOs and think tanks appear to be growing in strength and number. ${ }^{193}$ Yvonne Vissing predicts that norms will change organically through an emerging "child rights movement" to create the conditions necessary for ratifying the CRC. ${ }^{194}$ Although uncoordinated as of yet, Vissing is optimistic that local efforts will create the groundswell of support needed to drive the campaign to ratify the CRC. As a part of this overall organic

184. $I d$.

185. Unif. Parentage Act (2017) $\S 607$ (adjudicating genetic parental claims), 608 (adjudicating presumed parental claims).

186. See Vissing, supra note 2, at 94.

187. Revaz, supra note 3 , at 9.

188. Id. at 10. "The CRC broadly reflects the view that the child is not a chattel, but a human being in his or 1her own right.").

189. Id. at $10-11$.

190. Id. at 10 .

191. Id.

192. See Vissing, supra note 2 , at 88 .

193. Id. at $88,92-93$.

194. Id. at $87-95$. 
child rights movement, there continues to be a need for insiders in courts who can create the intentional, incremental shifting of norms necessary for the CRC principles to become normalized in the discourse about children and their rights vis-à-vis their parents and the state.

In addition to sources of advocacy for children's rights outside the institution of United States courts, there are signs of progress being made by insiders with the integration of international human rights law in a few critical cases. Cases such as Beharry v. Ashcroft, ${ }^{195}$ Lawrence v. Texas, ${ }^{196}$ Ayala-Caballero v. Coleman, ${ }^{197}$ and Naoum v. Attorney General of U.S. ${ }^{198}$ show some reliance on international precedent, but not wholehearted reliance and adoption of international legal precedent. ${ }^{199}$ In contrast, the United States penal system shows greater signs of change toward accepting international human rights law; human rights cases that move through the state courts up to the federal courts are beginning to appeal to the value of international human rights rules. ${ }^{200}$ One of the few standout cases that acknowledges international influence is Roper $v$. Simmons, which abolished the death penalty for minor children in the United States. ${ }^{201}$ In Roper, the paragraph that references international law does so with a caveat and cabins off international law as purely persuasive: "The opinion of the world community, while not controlling our outcome, does provide respected and significant confirmation for our own conclusions." 202 The Court's sentiment may seem as though it is too little too late to affect the lives of upwards of 200,000 children processed each year as adults in United States courts, ${ }^{203}$ but it is a significant breakthrough that promises continued progress. Recently, the movement toward acknowledging and being persuaded by international legal sources, particularly in the area of children's rights, has been successful in the area of juvenile justice initiatives. ${ }^{204}$ These initiatives are rooted in United States civil rights concerns based on the unequal treatment of children because of racial identity. ${ }^{205}$ For example, one of

195. Beharry v. Ashcroft, 329 F.3d 51, 55 (2003).

196. Lawrence v. Texas, 539 U.S. 558, 560 (2003).

197. Ayala-Caballero v. Coleman, 58 F. App'x 669, 672 (9th Cir. 2002).

198. Naoum v. Att'y Gen. of U.S., 300 F. Supp. 2d 521, 527 (N.D. Ohio 2004).

199. Ursula Kilkelly, Strengthening the Framework for Enforcing Children's Rights: An Integrated Approach, in Children's Human Rights: Progress and ChalLenges for Children Worldwide 71-73 (Mark Ensalaco \& Linda C. Majka eds., 2005).

200. See, e.g., Roper v. Simmons, 543 U.S. 551, 576-78 (2005).

201. Id.

202. Id. at 578 .

203. Children and Adolescents in the United States' Adult Criminal Justice System, supra note 77 , at 9 .

204. Dohrn, supra note 22, at 83-84.

205. Id. at $73-74$. 
the main drivers in juvenile justice cases, such as Roper $^{206}$ and Miller v. Alabama, ${ }^{207}$ was the data gathered about the unequal treatment of children of color. ${ }^{208}$

Rather than simply addressing juvenile justice as a concern because of children's status as children, both the principle of unequal treatment based on racial identity and the international human rights principle embodied in the CRC would prevent children from being sentenced with the death penalty. ${ }^{209}$ In the United States, children of color at every stage of the process, including the pipeline from family removal to foster care and then to juvenile delinquency proceedings and jail, are consistently overrepresented. ${ }^{210}$ One could argue that supplying scientific evidence to courts about children's diminished capacity is an oblique effort to demonstrate that childhood should be treated as a legal status.

However, in United States juvenile justice cases, neuroscience and physiological evidence were supplied to the courts in tandem with the civil rights aspect of the juvenile justice cause advocacy. ${ }^{211}$ Without the civil rights aspect, it is difficult to imagine that the cases would have had much traction with the court. The continued use of rhetoric about the overrepresentation of children of color involved in criminal cases, sounding in equal protection-treating all children the same, regardless of racial identity-does not result in sustainable change for all children. ${ }^{212}$ The United States has a past and present full of racial injustice, manifested in the hugely disproportionate number of people of color regulated by the state in negative ways-either through welfare and dependency or through the criminal justice system. ${ }^{213}$ For the children's criminal cases, in large part because the crimes are so serious, children are often tried in adult criminal court, demonstrating an

206. 543 U.S. at 578-79.(abolishing the death penalty for juveniles).

207. Miller v. Alabama, 567 U.S. 460, 489 (2012) (holding that juvenile life without the possibility of parole is unconstitutional).

208. Brief for NAACP Legal Defense \& Educational Fund, Inc. et al. as Amici Curiae Supporting Respondents at 1-2, Roper v. Simmons, 543 U.S. 551 (2005) (No. 03-633), 2004 WL 1636450; Brief for NAACP Legal Defense \& Education Fund, Inc. et al. as Amici Curiae Supporting Petitioners at 4-5, Miller v. Alabama, 567 U.S. 460 (2012) (No. 10-9646, 10-9647), 2012 WL 135045.

209. Children and Adolescents in the United States' Adult Criminal Justice System, supra note 77, at 70-71 (2018).

210. Id. at 71 .

211. See Hilary Rosenthal, Scanning for Justice: Using Neuroscience to Create a More Inclusive Legal System, 50 Colum. Hum. RTs. L. Rev. 290, 303 (2019); see also Miller, 567 U.S. at 471-72 (relying on prior precedents' use of neuroscience technology to differentiate between adolescents and adults); Graham v. Florida, 560 U.S. 48, 68 (2010) (using recent neuroscience findings to support inherent differences in decision-making between adolescents and adults).

212. See generally Khiara M. Bridges, Excavating Race-Based Disadvantage Among Class-Privileged People of Color, 53 Harv. C.R.-C.L. L. Rev. 65 (2018); Dorothy E. Roberts, The Social and Moral Cost of Mass Incarceration in African American Communities, 56 Stan. L. Rev. 1271 (2004).

213. See Bridges, supra note 212, at 124; Roberts, supra note 212, at 1272. 
underlying belief that the seriousness and adult-like nature of behaviors $^{214}$ signifies a child's heightened capacity instead of a child's heightened susceptibility to influence and coercion and the child's undeveloped decision-making abilities. ${ }^{215}$ Often, the children prosecuted in such cases received worse sentences than adults convicted of the same crimes. ${ }^{216}$

The intertwining of racially-informed civil rights is not a negative movement, and it should not be ignored or undermined. Rather, to make the next move to implement fully the greatest legal protection available, the United States should look to international human rights legal precedents to recognize and protect all children's rights because of their status as children and rights holders. In doing so, more children would have greater legal protection because protection would not just come from race-based discriminatory externalities. While certainly race, gender, gender identity, sexual orientation, class, religion, national origin, and other external identities should continue to inform decision-making and data gathering to guard against the unequal treatment of similarly situated persons, moving the baseline toward treating all children well because of their status as human children would be a significant positive gain. Identity markers beyond that of human childhood should not have to exist for children to be treated well, just as they should not authorize the worse treatment of some children as compared to others.

What should be a very compelling motivating factor for ratifying the $\mathrm{CRC}$ is the positive economic benefit to be had for significantly more children; the CRC aims directly at improving well-being through decreasing poverty. The famous "concentric circle" model by Stefan de Vylder demonstrates the positive macroeconomic benefits of the CRC. ${ }^{217}$ The concept at the heart of de Vylder's model is that of antipoverty aims. ${ }^{218}$ At the very center of the concentric circles lie the "policies and legislation which explicitly target children, 'such as provision[s] of primary health and education, and regulations against ex-

214. See William Binchy, The Adult Activities Doctrine in Negligence Law, 11 WILLiam Mitchell L. Rev. 733, 735 (1985) (stating United States torts principles allow children to bear civil liability when engaged in adult-like activities); Jackson v. McCuiston, 448 S.W.2d 33, 33, 35 (Ark. 1969) (explaining adult-like activities can include driving a tractor off of a main road or highway); Goodfellow v. Coggburn, 560 P.2d 873, 874 (Idaho 1977).

215. See Dohrn, supra note 22, at 83 (citing Graham v. Florida, 560 U.S. 48, 68-69 (2010) (regarding a child's diminished capacity to resist influence and become implicated in felony murder cases)).

216. See Sarri \& Shook, supra note 10, at 209 (explaining that children convicted of aggravated assault received prison sentences more often than adults).

217. Mac Darrow, Between Light and Shadow: The World Bank, the International Monetary Fund and International Human Rights Law 62 (2003) (citing Stefan de Vylder, Development Strategies, Macro-Economic Policies And the Rights of the Child 9 (1996)).

218. Id. 
ploitative child labour." "219 In the next circle, there are "policies and institutions that have a strong, but more indirect effect, and which are basically mediated through their impact on the child's family and parents." 220 These institutions that have a strong, indirect effect on children, mediated through families (what better description of United States domestic relations courts?), could be the site for interventions that intertwine CRC principles about the fundamental humanity of children with anti-poverty objectives envisioned by de Vylder. Another related argument for ratifying the CRC imagines using the CRC as an instrument to boost reform in the United States welfare and dependency system that exists as " a patchwork of federal, state and county dollars reaching into the billions,' which are not sufficiently integrated and lack accountability to the child." ${ }^{221}$ Considering the stunning number of children living in poverty in the United States, as reported by Phillip Alston, and the extremely large amount of money that may not be reaching children, it is incumbent that the United States consider solutions like the CRC while fighting against childhood poverty. ${ }^{222}$

\section{Radical Reform in Domestic Relations Courts}

One way to implement aspirational human rights mandates and maximize potential impact may be to find domestic settings that are particularly responsive to norm-setting. ${ }^{223}$ Rather than attempting a formal adoption and implementation method for integrating international human rights into the domestic system, it is possible to take the approach used by other countries when there has been resistance to the principles in international human rights treaties. ${ }^{224}$ By finding a norms-responsive legal setting, the work of normalizing new normsand even the implementation of said norms - can be done before formal ratification, much like the progress made in other countries. ${ }^{225}$

The CRC is a uniquely appropriate convention for a nation like the United States to use as a model for deriving principles to respond to complex international issues that are becoming domestically salient. Combining the norms-setting expressive function of adopting children's human rights principles with the unique conditions that make

219. Id.

220. Asher Ben-Arieh et Al., Measuring and Monitoring Children's WeLl-Being 57 (7th ed. 2001).

221. Kimberly Svevo-Cianci \& Sonia C. Velazquez, Companion Piece, Convention on the Rights of the Child Special Protection Measures: Overview of Implications and Value for Children in the United States, 89 Child Welfare 139, 140 (2010) (citation omitted).

222. See generally Alston, supra note 16.

223. Margaret E. Keck \& Kathryn Sikkink, Transnational Advocacy Networks in International and Regional Politics, 51 InT'L Soc. SCI. J. 89 (1999).

224. Id.

225. Id. 
institutions susceptible to change-in this case, domestic relations courts - is a way for children's rights advocates to normalize the principle of children as human rights holders and create value in international human rights law through "conversion." The "conversion" process by which "institutional challengers may be able to exploit its inherent ambiguities in ways that allow them to redirect it toward more favorable functions and effects" 226 is a methodology well-suited to domestic relations courts. In this case, to change the United States's children's rights norms to include international human rights principles, "conversion" could provide progress-minded institutional players with a strategy for incrementally changing the courts to begin speaking in the language of international human rights principles without requiring them to advocate for the larger, external change of ratification to a different branch of government. ${ }^{227}$ In both content and process, domestic relations courts are uniquely well-positioned to begin incremental change through "conversion" while holding out the aspirational vision of transformative change to the system at large.

United States domestic relations courts are currently a site for contemplating children's interests. Everyday matters, including children's welfare and dependency, divorce, and custody, have a close relationship with social norms and legal decision-making. Thus, introducing and adopting international human rights norms found in the CRC could be a natural place of growth for an institution susceptible to change because of the capacity to be flexible in the shifting norms. It could also be the setting for conscious, deliberate change through institutional change theory. Rather than waiting for legislative solutions that cannot be realized because there is no underlying acceptance of external legal frameworks-i.e., political resistance to ratifying the $\mathrm{CRC}$ - advocates should begin intentionally strategizing now to implement the CRC's principles into practice. While there are efforts being made by NGOs and other third-party actors within the state institution itself, there is currently no path forward for formally ratifying and implementing the CRC in the United States. ${ }^{228}$ Supporting external NGOs with internal, intentional action within the legal system could provide the impetus for transformative change.

In domestic relations courts, sweeping change does not typically happen in response to "big shocks"; instead it comes from "incremental change with transformative results." ${ }^{229}$ One has only to look at Kimberly Richman's collection of fifty years of case law from United States domestic relations courts to see the slow build toward parenting

226. Mahoney \& Thelen, supra note 27 , at 17-18.

227. See id. at 17-28.

228. See Vissing, supra note 2, at 88, 92-93.

229. Beyond Continuity: Institutional Change in Advanced Political ECONOMies 9 (Wolfgang Streeck \& Kathleen Thelen eds., 2005). 
equality for gay and lesbian parents. ${ }^{230}$ Fifty years may seem too long to wait for change to an institution. However, the change reflected in Richman's data set demonstrates that although there were few cases at the beginning, during the last decade the cases increased in number and quality such that most of the progress was made very quickly relative to the amount of time captured by the data set. ${ }^{231}$ Alison Gash's theory is that civil rights advocacy performed in relatively unseen, unmonitored spaces can be vital to success in securing rights. ${ }^{232}$ While advocacy work that Richman has captured is critical, the next phase of advocacy for parenting equality is ongoing. Not surprisingly, given the growing social acceptance of LGBT families, cases have shifted from contested custody cases between heterosexual and homosexual parents to questions of parentage. ${ }^{233}$ NeJaime's study of three non-biological lesbian mothers' quest for parentage in California ${ }^{234}$ is an example of continuing incremental progress and a shift toward parentage in cause-advocacy work. Goldberg's analysis of the Alison D. case is an example of cause advocacy performed in the understated setting of domestic relations courts. ${ }^{235}$

Ironically, the same system that can incorporate progressive ideals over a relatively short amount of time is also susceptible to absorbing less-than-ideal norms. An example of how quickly norms are absorbed is the quasi-scientific phenomenon of "parental alienation syndrome." Although lacking in any reliable or credible scientific testing or theory, the so-called syndrome was introduced through father's rights advocacy groups into domestic relations courts. ${ }^{236}$ Within only a few years, it infiltrated multiple courts and became a basis for granting greater custodial and visiting privileges to fathers. ${ }^{237}$ Even after the scientific community roundly condemned the practice of relying on

230. See Kimberly D. Richman, Courting Change: Queer Parents, Judges, and the Transformation of American Family Law 179-87 (2009).

231. See id.

232. Alison L. Gash, Below the Radar: How Silence Can Save Civil Rights 5-6 (2015) (detailing how quietly advocating for rights can prevent backlash from political opponents).

233. Richman, supra note 230, at 166.

234. Douglas NeJaime, Marriage Equality and the New Parenthood, 129 Harv. L. REV. 1187, 1222-29 (2016).

235. Suzanne B. Goldberg, Family Law Cases as Law Reform Litigation: Unrecognized Parents and the Story of Alison D. v. Virginia M., 17 Colum. J. Gender \& L. 307 (2008).

236. Michele A. Adams, Framing Contests in Child Custody Disputes: Parental Alienation Syndrome, Child Abuse, Gender, and Fathers' Rights, 40 FAM. L. Q. 315, 315-16, 326 (2006).

237. Joan S. Meier, U.S. Child Custody Outcomes in Cases Involving Parental Alienation and Abuse Allegations: What Do the Data Show?, 42 J. Soc. Welfare \& FAM. L. 1, 6-8 (2020) (showing that when mothers alleged abuse and fathers alleged alienation, fathers prevailed by a significant percentage over mothers in custody determinations). 
"parental alienation syndrome," the idea still persists in courts. ${ }^{238}$ It became a "sticky" idea that cannot seem to be shaken despite the dearth of scientific evidence for the idea. ${ }^{239}$ If ideas that are harmful to children are that easy to introduce to courts, it is that much more compelling for children's rights advocates to introduce strategically child-positive concepts into courts.

The CRC provides a core concept-children as rights holders because of their status as human beings-that is simple in theory, but from which so many radical and positive reforms could spring that it would be a tragic oversight to miss the opportunity to make it available to courts that have direct contact with children. Imagine that children's views, interests, and desires were considered, not as aspirational matters, but as matters of protecting their legal rights. The current climate change litigation, ${ }^{240}$ the aftermath of mass shootings like Parkland, ${ }^{241}$ Sandy Hook,${ }^{242}$ or the West Nickel Mines ${ }^{243}$ that took the lives of several school children, and the detention centers at the United States and Mexico border ${ }^{244}$ are a few examples of the areas where there are gaps between children's rights and legal remedies that are child-centric. Attacking the problems that detrimentally affect children's rights to live in a safe, ecologically sustainable environment free of violence, poverty, and separation from their caregivers through legislation or the executive branch of government does not fundamentally differ from the current approach of adults advocating for children's protection. The key difference in treating children as rights-holders instead of objects of protection is that children would have a voice and causes of action for the harms they suffer,

238. Joan B. Kelly \& Janet R. Johnston, The Alienated Child: A Reformulation of Parental Alienation Syndrome, 39 FAM. CT. Rev. 249, 250 (2001).

239. Adams, supra note 236, at 326.

240. See Juliana v. United States, Our CHILd.'s Tr., https://www.ourchildrenstrust. org/juliana-v-us (Mar. 9, 2021) [https://perma.cc/NAH6-LZFE]; Press Release, Our Children's Trust, Decision of Divided Ninth Circuit Court of Appeals Finds Primarily for Juliana Plaintiffs, but Holds Federal Judiciary Can Do Nothing to Stop the U.S. Government in Causing Climate Change and Harming Children (Jan. 17, 2020), https://static1.squarespace.com/static/571d109b04426270152febe0/t/5e22508873d1bc 4c30fad90d/1579307146820/Juliana+Press+Release+1-17-20.pdf [https://perma.cc/BH 9X-XNVL] (citing the court's opinion that, "federal courts cannot provide the youth with a remedy for their climate change injuries," and instead urging them to consider executive and legislative remedies).

241. Dakin Andone, It's Been 2 Years Since the Deadly Shooting at a High School in Parkland, Florida, CNN, https://www.cnn.com/2020/02/14/us/parkland-shootingmarjory-stoneman-douglas-2-years/index.html (Feb. 14, 2020, 11:16 AM) [https:// perma.cc/5GFL-M6XQ].

242. Sandy Hook School Shootings Fast Facts, CNN, https://www.cnn.com/2013/06/ 07/us/connecticut-shootings-fast-facts/index.html (Dec. 2, 2020, 6:24 PM) [https:// perma.cc/LM5S-WXXU].

243. David Kocieniewski \& Gary Gately, Man Shoots 11, Killing 5 Girls, in Amish School, N.Y. Times (Oct. 3, 2006), https://www.nytimes.com/2006/10/03/us/ 03amish.html [https://perma.cc/K9MB-8MVC].

244. Nixon, supra note 76. 
providing a legal avenue for advocacy and recourse. The fight should be taken to places where it is normal to consider the interests of the child at bar, not the interests of all children everywhere. It is possible that in learning how to truly take children's rights seriously, and not merely as a cover for adults' rights, on an individual basis and using principles that stress the value of all children, advocacy for children's rights writ large can be realized.

After more than twenty years since the creation of the CRC, it would seem that a new approach to motivating the United States to ratify the CRC should be taken. In the United States, there is little-tono understanding of capacity building and no desire to implement international treaties, leaving few options except to utilize institutional change theory to realize international human rights law in the present to create the conditions for ratification. In addition to the continuing efforts of lobbyists, NGOs, and other advocacy networks, institutional players themselves should join in the work of promoting children's rights. The time is now to begin strategically harnessing settings where legal advocacy has been driven through case-by-case incremental wins and slow-moving normalization of new standards rather than a topdown federalism legal "imposition" of political ideology.

Acrimonious partisan rhetoric in the United States continues to present obstacles to both international human rights treaty ratification $^{245}$ and fulfilling the aims of the CRC. ${ }^{246}$ Social and religious conservative political rhetoric undermines the possibility of international influence in spaces believed to be almost sacred legal doctrine-those of family privacy. ${ }^{247}$ On the national stage, partisan debates and entrenched positions can be maintained and deployed for political gain, but at the domestic level, judges cannot embrace deeply partisan stances without running the risk of losing elections, being removed for cause, or not being reappointed. There are some judges in regions of the United States who are supported in their socially conservative decisions, but those judges tend to become outliers quickly by their decisions either being overturned by higher courts or being out of step with other state jurisdictions addressing similarly situated litigants. Thus, domestic courts are extremely responsive to norm setting because judges must address the person(s) at bar, not imagined figures presented as part of a national partisan narrative. The reality of domestic relations courts is that the lives and well-being of individual

245. See Curtis A. Bradley, The United States and Human Rights Treaties: Race Relations, the Cold War, and Constitutionalism, 9 CHINESE J. INT'L L. 321, 328 (2010).

246. See generally Jeffrey S. Peake, Coalition Building and Overcoming Legislative Gridlock in Foreign Policy, 1947-98, 32 Presidential Stud. Q. 67 (2002).

247. See Soo Jee Lee, Note, A Child's Voice vs. a Parent's Control: Resolving a Tension Between the Convention on the Rights of the Child and U.S. Law, 117 Colum. L. Rev. 687, 700-01 (2017); T. Jeremy Gunn, The Religious Right and the Opposition to U.S. Ratification of the Convention on the Rights of the Child, 20 EMORY INT'L L. REV. 111, 124 (2006). 
children and families are at stake. It is perhaps more difficult to rationalize unfairness, ignore expert findings, or maintain willful blindness to the best interests of the family and child(ren) at bar than to make sweeping generalizations in political settings. For example, when a child who experiences depression, suicidal ideation, and selfharm because of a desire to be identified as a gender different from the child's birth gender appears before a judge (and offers expert medical findings), partisan views about trans children should not be permitted to inform a legal opinion about the best interests of the child at bar. While the judge could have very different personal beliefs, judges who follow professional judicial ethical guidelines do not permit their personal beliefs to cloud their legal judgment. In this way, over time, advocacy groups have improved the lives of marginalized and disfavored family groups. Working women, single mothers, gender-non-conforming men, parents with disabilities, and lesbian and gay parents represent a few of the groups that have advocated and won incremental progress in domestic relations courts.

The norms that domestic courts are particularly responsive to include: (1) basing decisions on social science evidence; (2) valuing health outcomes data; and (3) having a strong interest in extra-jurisdictional social-legal trends that impact families. Some might argue that other courts (i.e., juvenile criminal cases) perform the same functions. This is not a zero-sum game; multiple court settings can be harnessed for furthering the cause of international human rights principles. The argument here is that domestic relations courts are uniquely situated to introduce a norm that is critical to embracing the CRC's larger goals - that of recognizing the ability of children to be rights holders based on their status as human children. While that argument could have been made in the realm of juvenile justice, the civil rights and equal protection thread of the argument was selected as a more persuasive tool to gain leverage with the courts and in the minds of the populace who often mistakenly see children of color as older than they are and as much more dangerous than white children. However, since children are likely to engage with domestic relations courts (regardless of their fit within a constitutionally protected suspect class) because of overwhelmingly common domestic legal matters, arguments about the human status of all children in domestic courts can have greater traction. With the understanding that domestic relations courts are often engaged in the business of working out cases on the bench regarding what the best interests of a child are at any given moment, it is not surprising that courts rely on external sources for guidance.

Courts are becoming increasingly familiar with social science evidence based on processing large swathes of data and longitudinal studies when making decisions about children. Social science outcomes were used to change laws regarding parenting equality. Studies 
like those performed by Charlotte Patterson, a longitudinal study of minor children with lesbian and gay parents, ${ }^{248}$ combined with Nanette Gartrell's data following lesbian parents for over seventeen years ${ }^{249}$ contributed to a reversal in the law that prevented lesbian and gay parents from receiving custody without any opportunity to demonstrate parental fitness. ${ }^{250}$ As with juvenile justice advocacy, neurologists investigate minor children's capacity to make decisions; evidence from big data supports the suggestion that minor children's decision-making capacity is diminished as compared to a fully-developed adult. ${ }^{251}$ Another area where social science has improved decision-making is comparing data sets of married versus single parents. The popular belief that heterosexual pairings were the gold standard for marriage has been disrupted by a granular review of the data sets available. ${ }^{252}$ The comparison between single mothers and married heterosexual couples did not account for the baseline difference in income and attention from adults flowing to the children. Rather than suggesting that parents needed to be heteronormative to be successful, the data suggests that children with more than one parent or adult contributing income and attention tend to do better than those with less. ${ }^{253}$ That does not mean a single parent is, by definition, going to have a worse outcome; many single parents build networks that operate much like a heteronormative family structure. ${ }^{254}$ The careful review of data also suggests that the gender of the parents is not instrumental in the outcomes for the children. ${ }^{255}$ Therefore, it is not requisite for a child to have a father and a mother. Rather, having more than one parental figure produces the best outcomes. ${ }^{256}$ The focus in social science data is now on attachment as a part of a child's development. The social workers' brief in the case of Brooke S. B. exemplifies the turn toward developmental science. ${ }^{257}$

248. See generally Charlotte J. Patterson, Children of Gay and Lesbian Parents, 15 Current Directions Psych. Sci. 241 (2006).

249. See generally Nanette K. Gartrell, Henny M.W. Bos, \& Naomi G. Goldberg, Adolescents of the U.S. National Longitudinal Lesbian Family Study: Sexual Orientation, Sexual Behavior, and Sexual Risk Exposure, 40 Arch. Sex Behav. 1199 (2011).

250. See generally Richman, supra note 230 (tracking the relaxation of legal standards imposed on parents deemed per se unfit to parent because of sexual orientation status over time).

251. See Sarah-Jayne Blakemore \& Trevor W. Robbins, Decision-Making in the Adolescent Brain, 15 Nature Neuroscience 1184, 1186 (2012).

252. See Leslie Cooper \& Paul Cates, Too High a Price: The Case Against Restricting Gay Parenting ch. 4 \& ch. 6 (2d ed. 2006).

253. Id. at 33-34.

254. Id.

255. Id.

256. Id.

257. Brief Amicus Curiae of the National Association of Social Workers, the National Association of Social Workers' New York State Chapter, and the National Association of Social Workers' New York City Chapter in Support of PetitionerRespondent, Brooke S.B. v. Elizabeth A.C.C., No. APL-2015-00236, 7-16 (March 18, 2016). 
Health outcomes serve to broaden the scope of factors that courts can consider during legal determinations about a child's best interest. Courts cited to health outcomes when making child custody decisions regarding bonding between the parent and child. ${ }^{258}$ What used to be the tender years doctrine based on social norms of motherhood and young children was reversed because it was perceived as sexist. ${ }^{259}$ Health-outcome data now shows that bonding and attachment shortly after birth is critical for neurological and physiological development. ${ }^{260}$ The health-outcome data does not mandate that it has to be the birth mother providing care but does strongly suggest that children have better health outcomes during the newborn and early developmental stages when they are nurtured by a parent or parents. ${ }^{261}$ While there are equal protection concerns that prohibit a court from wholesale mandating that women who give birth to children must provide personal care to their children, there is data to support a mother's choice to breastfeed and provide care for a child. ${ }^{262}$ If a judge were ordering a schedule for equally fit parents to have time with a child, considering health-outcome data might militate toward creating a visitation schedule that supports one parent's ability to breastfeed rather than pedantically dividing a week in half without regard for the child's or breastfeeding woman's schedule. In cases where childhood obesity impacts custody decisions, ${ }^{263}$ court decisions are inconsistent. ${ }^{264} \mathrm{Al}$ though it is evident that obesity is harmful to a child's health, it is unclear that a parent controls a child's weight gain in the same way that a parent might harm a child by keeping the child on an overly restrictive diet. ${ }^{265}$ In cases where parents have insisted on a vegan or vegetarian diet for their children that has resulted in severely undernourishing their children, courts have removed the children to prevent

258. Steven N. Peskind, Determining the Undeterminable: The Best Interest of the Child Standard as an Imperfect but Necessary Guidepost to Determine Child Custody, 25 N. ILl. U. L. Rev. 449, 454-55 (2005); Tiffany Korte, Comment, Terminally Ill Parents and Their Children: Determining the Proper Placement of Children Through the Best Interests of the Child or the Parental Preference Standard, 17 FLA. Coastal L. REv. 161, 166 (2015).

259. See generally WeIsBerg, supra note 56, at 662-65 (7th ed. 2020).

260. Robert Winston \& Rebecca Chicot, The Importance of Early Bonding on the Long-Term Mental Health and Resilience of Children, 8 LONDON J. PRIMARY CARE 12,12 (2016).

261. Id. at 12; see generally Jeannette Crenshaw, Care Practice \#6: No Separation of Mother and Baby, With Unlimited Opportunities for Breastfeeding, 16 J. Perinatal EDUC. 39 (2007).

262. Kim H. Pearson, Chemical Kids, 24 Tex. J. Women, Gender, \& L. 67, 83-84 (2014); Winston \& Chicot, supra note 260, at 13; see generally Crenshaw, supra note 261.

263. Pearson, supra note 262, at 80.

264. Jenna T. Hayes \& Lorie L. Sicafuse, Is Childhood Obesity a Form of Child Abuse? Factors to Consider in Judicial Rulings, 94 Judicature 20, 21-22 (2010).

265. Id. at 25 . 
further harm. ${ }^{266}$ Childhood obesity does not operate in the same way. The few attempts to remove children from parents because of the harmful nature of obesity have been met with popular resistance. ${ }^{267}$ Finally, courts have relied on health outcomes to restrict the use of substances during pregnancy. Dorothy Roberts critiques the regulation and criminalization of women of color through restrictions on their prenatal behavior. ${ }^{268}$ Even though this is a contested space, the example demonstrates that courts rely heavily on health outcomes to regulate other behaviors. ${ }^{269}$

Courts look to extra-jurisdictional decisions because of quickly changing demographics and social norms. It is quite typical for state courts to check their sister jurisdictions when they have an issue that they have not seen before. In particular, biotech-related growth areas such as surrogacy, artificial reproductive technology ("ART"), embryo-freezing and custody, plastic surgery for children, cochlear implants, and hymenal rejuvenation or replacement represent a few of the issues that are still a patchwork of rulings or are just making their way through courts now. Heightened consciousness of extra-jurisdictional decision-making most likely derives from the laboratory model of legal responses to social norm shifts and gaps in rules. That being the norm and practice, it is a system set up to obtain the best that "conversion" has to offer. Institutional insiders paired with external non-institutional actors (NGOs, transnational advocacy groups, etc.) could engage in "information exchange." ${ }^{270}$ They could work together to build a network to "mobilize information strategically to help create new issues and categories, and to persuade, pressurize, and gain leverage over much more powerful organizations and governments." 271 Then, institutional insiders could begin deploying ideas and rhetoric to move the institution toward the CRC's core principles with the hope of transformative change in the future. Yanbai Andrea Wang's theory that the implementation of treaties, not the "doctrinal meaning," in their "complex, decentralized, and oftentimes opaque" processes leads to transformative change is certainly relevant here. ${ }^{272}$

266. Mary Elizabeth Williams, Is Veganism Child Abuse?, SAlon (June 26, 2014, 6:37 PM), https://www.salon.com/2014/06/26/is_veganism_child_abuse/ [https:// perma.cc/FZF8-TPPH]; Tanya Di Genova \& Harvey Guyda, Infants and Children Consuming Atypical Diets: Vegetarianism and Macrobiotics, 12 Pediatrics \& Child Health 185, 187 (2007).

267. See generally H.R. Clark et al., How Do Parents' Child-Feeding Behaviours Influence Child Weight? Implications for Childhood Obesity Policy, 29 J. PuB. HeAlth 132 (2007); Genova \& Guyda, supra note 266.

268. See generally Dorothy E. Roberts, Punishing Drug Addicts Who Have Babies: Women of Color, Equality, and the Right of Privacy, 104 Harv. L. REv. 1419 (1991).

269. Id.

270. Keck \& Sikkink, supra note 223, at 65-66, 71.

271. Id. at 89.

272. Yanbai Andrea Wang, The Dynamism of Treaties, 78 MD. L. REv. 828, 848 (2019). 
She argues that "implementation-level changes did not constitute 'subsequent practice' for purposes of interpretation under the Vienna Convention, yet their scope was vast, and they precipitated more formal, legislative updates later on." 273

The most striking example of incremental change leading to a change in national norms is parenting equality. After over fifty years of advocating for parenting equality for lesbian and gay parents, the same arguments that supported keeping children with parents-regardless of sexual orientation-reappeared in legal arguments heard at the United States Supreme Court. Per Gash's argument, this advocacy feat was accomplished because it happened quietly over time and under the radar of national attention. ${ }^{274}$ The Supreme Court of the United States's rulings become federal law, setting the legal standard for all lower courts. So, although parenting equality is concerned with parent-child relationships, the idea of marriage equality in the United States is so strongly intertwined with parenting that marriage equality needed the incremental evidence of positive incremental change in domestic relations courts before it could reach the transformative change allowing marriage equality. There is no reason that a similar strategy should not be used in efforts to incorporate the baseline tenets of the CRC into United States domestic relations courts. The possibilities for transformative change could lead to unexpected positive outcomes for children and families.

\section{Conclusion}

The call to implement the CRC into United States domestic relations courts through institutional "conversion" is a call to action and a call for patience. It requires advocates to press forward with an objective while living with the uncertainty of making slow, uneven progress toward that objective. There will be case outcomes signaling acceptance of the CRC, just as there will be courts that reject the CRC. One has only to look at the juvenile justice legal landscape to see that progress in protecting children from life sentences has not been a straight line from Point A (these punishments are inhumane) to Point B (children are no longer subject to such punishments because they are human children). ${ }^{275}$ Instead, research and targeted legal action was required to demonstrate that children have diminished decision-making capacity, and the system unfairly punishes children of color and of

273. Id. at 833 .

274. GAsH, supra note 232.

275. Sarah French Russell, Jury Sentencing and Juveniles: Eighth Amendment Limits and Sixth Amendment Rights, 56 B.C. L. REv. 554, 560-64 (2015); see generally Miller v. Alabama, 567 U.S. 460, 465 (2012) (finding mandatory life without parole sentences for juveniles unconstitutional); Graham v. Florida, 560 U.S. 48, 74 (2010) (finding life without parole sentences unconstitutional for juveniles who have committed nonhomicide offenses); Roper v. Simmons, 543 U.S. 551, 578 (2005) (finding the death penalty for juveniles unconstitutional). 
low-income status. Despite the progress in aiding incarcerated minor children, the current state of the law is again vulnerable to attack by a United States Supreme Court case that broadens the courts' ability to execute incarcerated prisoners without fear of larger social consequences or uprisings. Continuing forward in the face of seeming failure or defeat of the advocacy objective seems to be inherent in the project of implementing international human rights law generally, and definitely in the case of the CRC and the United States.

Calling for advocates to continue taking actions that may be accompanied by losses in litigation and advocacy efforts is challenging. Taleb describes how difficult it is to be a dissenter taking losses over time when it would be easier to go along with a system that is designed for short-term wins. ${ }^{276}$ In The Black Swan, his example of the lone dissenter is a trader who is willing to take small losses repeatedly over time while working toward fewer, but bigger, wins. ${ }^{277}$ This resulted in a loss of health and in suffering near daily doubts about himself and his actions because of the slow, steady losses he incurred. ${ }^{278}$ In the end, he won big but only after suffering for a significant amount of time during which he acted against his own short-term interest. ${ }^{279} \mathrm{In}$ the same way, it can be lonely, difficult work to advocate for children when there are significant structural and socio-legal forces arrayed against children and their advocates. The United States domestic legal system seems to be set up for immediate wins (i.e., the case of child custody determinations that focus on parents' individual arguing for the BIOC) rather than the longer, demanding challenge of finding mutually beneficial legal solutions for children, parents, and the state. If Todres is correct about the substantive political reasons for the United States's resistance to the CRC, ${ }^{280}$ it is also likely that advocacy groups are correct about the method for pressing forward with implementation of the CRC without directly addressing politics. Rather than siding with any particular political agenda or attempting to reenvision deeply held beliefs about constitutionally protected parenting interests and rights, advocates should focus on the principles enshrined in the CRC without naming them and formally advocating for ratification.

The value of patiently working on an extended time frame from multiple angles is that movement in some direction will certainly be made; the choice about which direction and how that direction is shaped is an ongoing conversation. The 2018 research report, Realising Rights? The UN Convention on the Rights of the Child in Court, demonstrates that there are various levels of acceptance and imple-

276. TALEB, supra note 40 , at $96-98$.

277. $I d$.

278. $I d$.

279. Id.

280. Todres, supra note 6 , at 20-21. 
mentation of the CRC's substantive principles across nation-states. ${ }^{281}$ Many nation-states are implementing the $\mathrm{CRC}$, and their domestic courts are interacting with the $\mathrm{CRC}$; just as with the change in religious reservations based on peer-nation influence noted by Başak Çali and Mariana Montoya, ${ }^{282}$ so too could the United States be persuaded by similarly situated peer nations to respond to the CRC. In the alternative, the report demonstrates that over time, targeting courts as a setting for advocacy and implementation of the CRC is a work in progress with slow, but steady improvements in the recognition and protection of children's rights. ${ }^{283}$

Until such a time, if ever, that the United States acts in its federal legislative capacity ${ }^{284}$ to dictate the ratification and implementation of the CRC, movement toward wholesale acceptance can only come from forces on the ground. The converging interests of non-governmental advocacy groups, public intellectuals, court officials, and families involved with the legal system are all positioned to coordinate and help transform domestic relations courts in the United States. The promise of transformative change that incorporates the principles of the CRC would provide durable, embedded, and substantive content into the very baseline conceptualization of children and their contact with the law. Cases and laws that are vulnerable to political capture are different from the kind of transformative change that institutional insiders can make. Institutional insiders can enact change like the BIOC standard that is no longer contested, but at the very heart of the substantive law for domestic relations legal disputes involving children. Rebuttable presumptions that favored parental interests over children's, like the "tender years" doctrine, have since been eradicated $^{285}$ and replaced with a policy that ostensibly focuses on children first. Now, it would be virtually unthinkable to promulgate laws and policies that undermine taking the BIOC into account. ${ }^{286}$ In a similar way, the CRC's principles should be integrated into the heart of the law and policy that touches children. Without diminishing the many good efforts that other advocates take to implement the CRC, and in fact, it is in support of all efforts that this narrow call to action and patience is made. The narrow scope of the call to influence domestic

281. See generally Realising Rights? The UN Convention on the Rights of the Child in Court, ChILd RTs. INT'L NeTwork (2018), https://archive.crin.org/sites/default/ files/uncrc_in_court.pdf [https://perma.cc/KU3J-PD35].

282. See ÇALI \& Montoya, supra note 111, at 3.

283. See generally Realising Rights? The UN Convention on the Rights of the Child in Court, supra note 281.

284. Merle H. Weiner, Beyond Other Treaties: The U.N. Convention on the Rights of the Child and the Value of "A Dedicated Line", in The U.N. Convention on the Rights of the Child: An Analysis of Treaty Provisions and Implications of U.S. Ratification 69 (Jonathan Todres, Mark E. Wojcik \& Cris R. Revaz eds., 2006).

285. See WeisBerg, supra note 56, at 665; Woodhouse, supra note 9, at 54 .

286. See Woodhouse, supra note 9 , at 55. 
relations courts to implement the CRC principles into cases is in reality a massive undertaking; in the United States, there are fifty states with numerous state and local courts. The courts represent a writhing mass of court officials and families wrestling with their individual problems and swiftly changing political and social norms. And yet, it is in this spirit of inchoate, yet harmonizing collective efforts that domestic court insiders can position themselves to transform the institution over time as part of a larger movement. The ability to hold both the individual legal situation in perspective with the global requires maintaining a vision that can value both the individual child at bar and all children in the world as humans deserving of rights. 